\title{
GTL-1 Irradiation Summary Report
}

D. M. Perez

G. S. Chang

N. E. Woolstenhulme

D. M. Wachs

January 2012

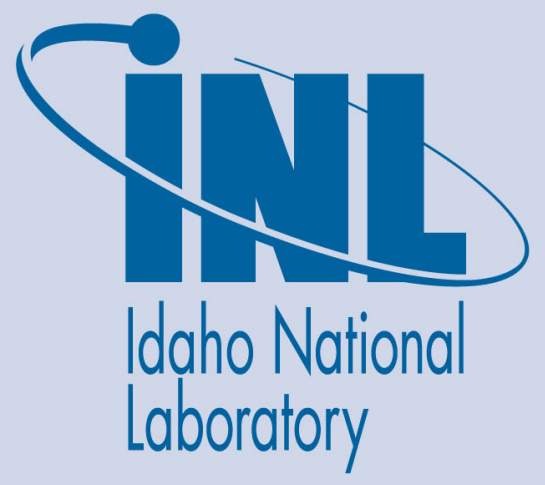

The INL is a U.S. Department of Energy National Laboratory operated by Battelle Energy Alliance 
INL/EXT-10-20546

\title{
GTL-1 Irradiation Summary Report
}

\author{
D. M. Perez \\ G. S. Chang \\ N. E. Woolstenhulme \\ D. M. Wachs
}

January 2012

\section{Idaho National Laboratory \\ Idaho Falls, Idaho 83415}

http://www.inl.gov

Prepared for the

U.S. Department of Energy

Office of National Nuclear Security Administration

Under DOE Idaho Operations Office

Contract DE-AC07-05ID14517 


\section{DISCLAIMER}

This information was prepared as an account of work sponsored by an agency of the U.S. Government. Neither the U.S. Government nor any agency thereof, nor any of their employees, makes any warranty, expressed or implied, or assumes any legal liability or responsibility for the accuracy, completeness, or usefulness, of any information, apparatus, product, or process disclosed, or represents that its use would not infringe privately owned rights. References herein to any specific commercial product, process, or service by trade name, trade mark, manufacturer, or otherwise, does not necessarily constitute or imply its endorsement, recommendation, or favoring by the U.S. Government or any agency thereof. The views and opinions of authors expressed herein do not necessarily state or reflect those of the U.S. Government or any agency thereof. 
GTL-1 Irradiation Summary Report

INL/EXT-10-20546

January 2012

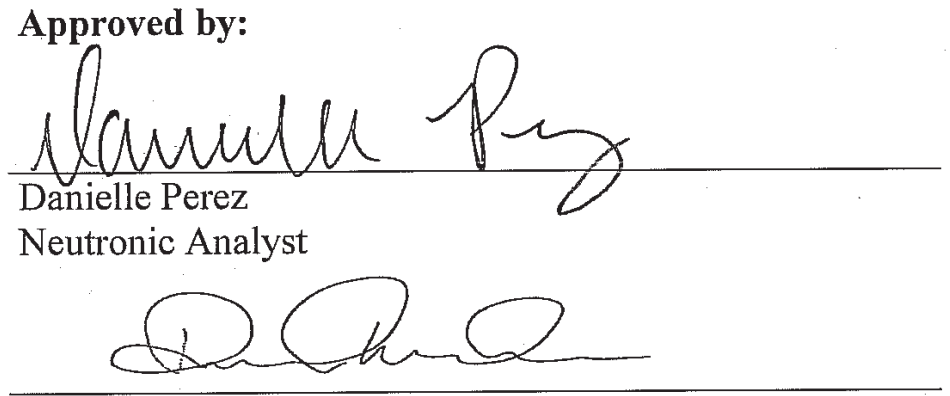

Daniel M Wacks

Principle Investigator

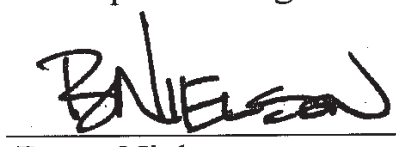

Bruce Nelson

Experiment Manager

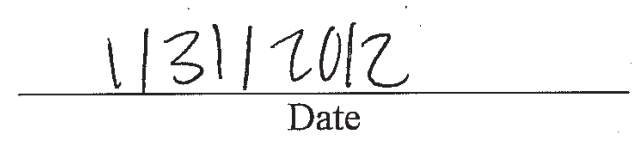

January 31,2012

Date

$$
\frac{1131 / 2012}{\text { Date }}
$$




\section{SUMMARY}

The primary objective of the Gas Test Loop (GTL-1) miniplate experiment is to confirm acceptable performance of high-density (i.e., $4.8 \mathrm{~g}-\mathrm{U} / \mathrm{cm} 3$ ) U3Si2/A1 dispersion fuel plates clad in Al-6061 and irradiated under the relatively aggressive Booster Fast Flux Loop (BFFL) booster fuel conditions, namely a peak plate surface heat flux of $450 \mathrm{~W} / \mathrm{cm} 2$. As secondary objectives, several design and fabrication variations were included in the test matrix that may have the potential to improve the high-heat flux, high-temperature performance of the base fuel plate design.1, 2

The following report summarizes the life of the GTL-1 experiment through end of irradiation, including as-run neutronic analysis, thermal analysis and hydraulic testing results. 


\section{CONTENTS}

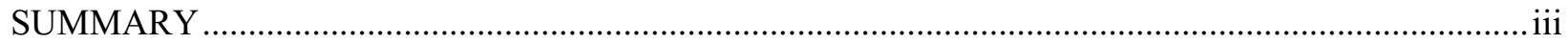

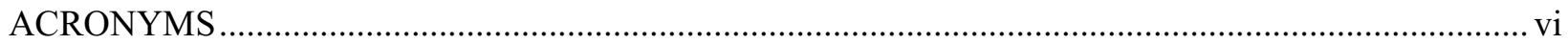

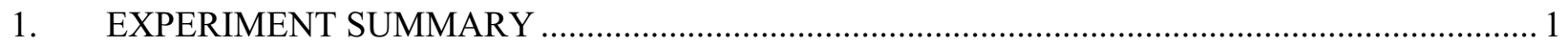

2. CONSTITUENT MASS, MASS DENSITIES AND ATOM DENSITIES ….............................. 3

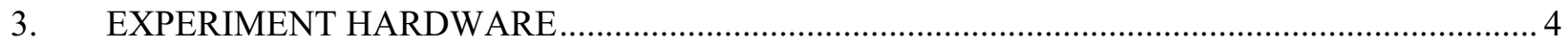

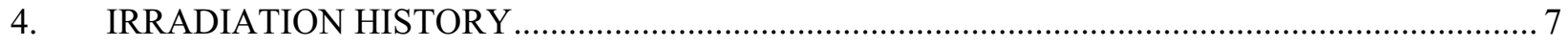

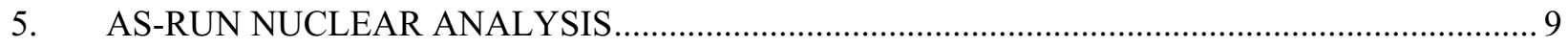

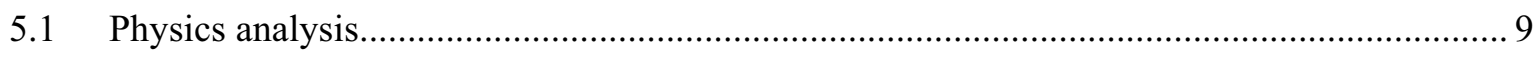

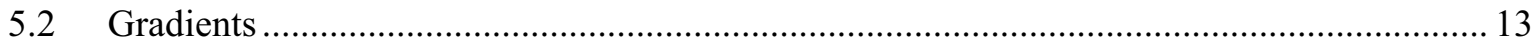

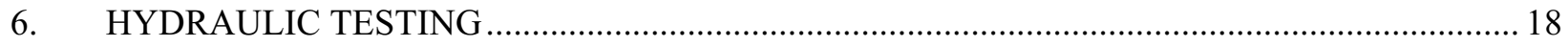

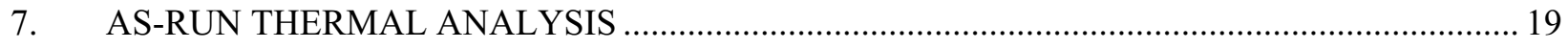

7.1 Coolant Temperature as a Function of Location ............................................................... 20

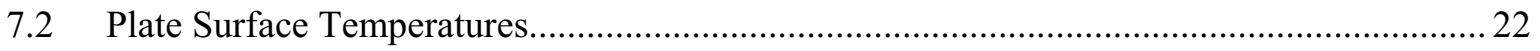

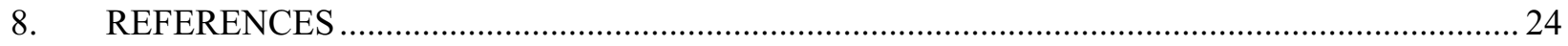

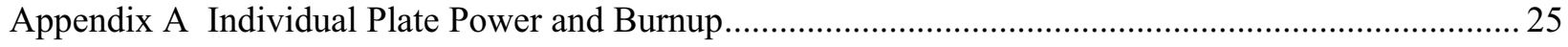

\section{FIGURES}

Figure 1. GTL-1 miniplate irradiation assembly (DWG 600448). .....................................................5

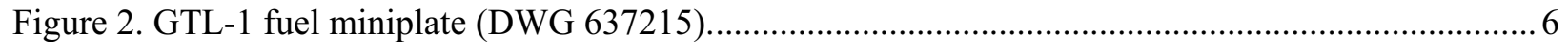

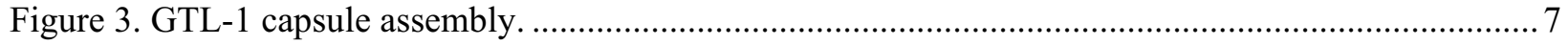

Figure 4. GTL-1 capsule cross section......................................................................................... 7

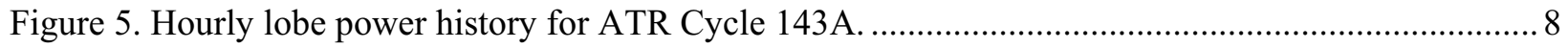

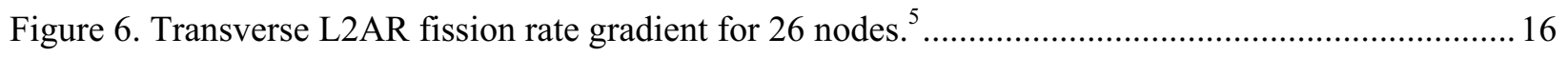

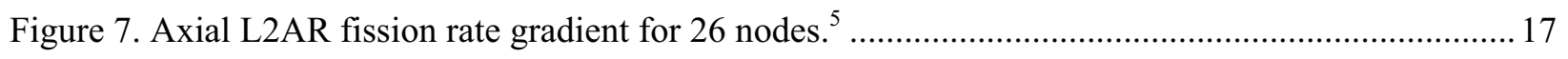

Figure 8. GTL-1 coolant channel temperature along the test assembly for Cycle 143A at 18

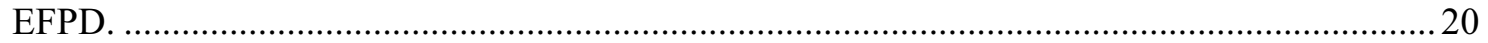

Figure 9. GTL-1 coolant channel temperature along the test assembly for Cycle 143A at 36 EFPD.

Figure 10. GTL-1 coolant channel temperature along the test assembly for Cycle 143A at 48.9 EFPD. 


\section{TABLES}

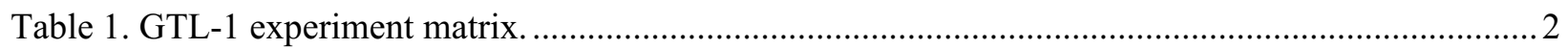

Table 2. As-built constituent mass, mass density and atom density for the GTL-1 miniplates. ${ }^{2} \ldots \ldots \ldots \ldots \ldots . . . . .3$

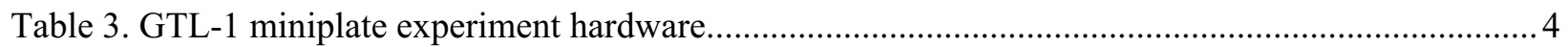

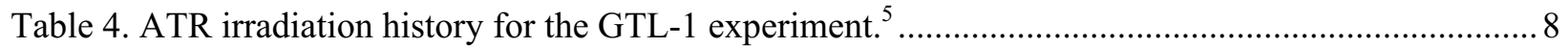

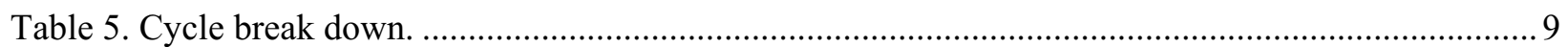

Table 6. GTL-1 fuel compact and processed fuel meat densities with the constituent as-built

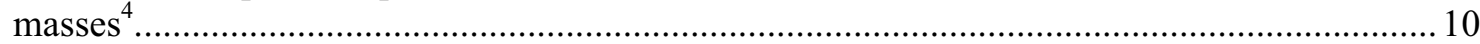

Table 7. BOC as-run GTL-1 calculated fission heating rates and U-235 burnup. ${ }^{5}$.................................. 11

Table 8. As-Run GTL-1 calculated fission heat rates and U-235 burnup at 18 EFPD. ${ }^{5}$.......................... 11

Table 9. As-Run GTL-1 calculated fission heat rates and U-235 burnup at 36 EFPD. ${ }^{5}$........................... 12

Table 10. EOC as-run GTL-1 calculated fission heat rates and U-235 burnup (48.9 EFPD). ${ }^{5}$.................. 12

Table 11. Fission rate L2AR in the miniplate fuel zone transverse direction for 26 nodes...................... 14

Table 12. Fission rate L2AR in the miniplate fuel zone axial direction for 26 nodes. ............................. 15

Table 13. Loss coefficients for the GTL-1 irradiation test vehicle components. ${ }^{6}$...................................... 18

Table 14. GTL-1 average, maximum and minimum plate surface temperatures for Cycle 143A at

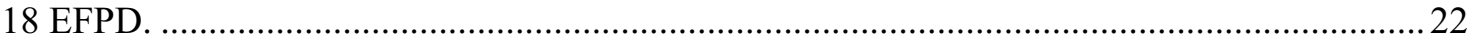

Table 15. GTL-1 average, maximum and minimum plate surface temperatures for Cycle 143A at

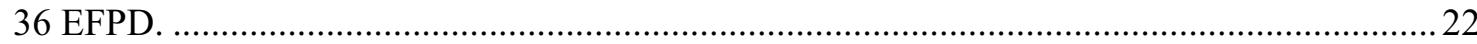

Table 16. GTL-1 average, maximum and minimum plate surface temperatures for Cycle 143A at 48.9 EFPD. 


\section{ACRONYMS}

$\begin{array}{ll}\text { Al } & \text { aluminum } \\ \text { ATR } & \text { Advanced Test Reactor } \\ \text { ATRC } & \text { Advanced Test Reactor Critical } \\ \text { BFFL } & \text { Booster Fast Flux Loop } \\ \text { BOC } & \text { beginning of cycle } \\ \text { DAS } & \text { Data acquisition system } \\ \text { EFPD } & \text { effective full-power day } \\ \text { GTL } & \text { Gas Test Loop } \\ \text { L2AR } & \text { local-to-average ratio } \\ \text { MCNP } & \text { Monte Carlo Neutral Particle } \\ \text { RERTR } & \text { Reduced Enrichment Research and Test Reactor } \\ \text { Si } & \text { silicon } \\ \text { SFT } & \text { South Flux Trap } \\ \text { U } & \text { uranium }\end{array}$




\section{GTL-1 Irradiation Summary Report \\ 1. EXPERIMENT SUMMARY}

The primary objective of the Gas Test Loop (GTL-1) miniplate experiment is to confirm acceptable performance of high-density (i.e., $4.8 \mathrm{~g}-\mathrm{U} / \mathrm{cm}^{3}$ ) $\mathrm{U}_{3} \mathrm{Si}_{2} / \mathrm{Al}$ dispersion fuel plates clad in Al-6061 and irradiated under the relatively aggressive Booster Fast Flux Loop (BFFL) booster fuel conditions, namely a peak plate surface heat flux of $450 \mathrm{~W} / \mathrm{cm}^{2}$. Additionally, miniplates operating at heat fluxes above 450 $\mathrm{W} / \mathrm{cm}^{2}$ and up to as high as $600 \mathrm{~W} / \mathrm{cm}^{2}$ were tested to demonstrate that a significant performance margin above this nominal, as-designed surface heat flux exists for the BFFL booster fuel elements. As secondary objectives, several design and fabrication variations were included in the test matrix that may have the potential to improve the high-heat flux, high-temperature performance of the base fuel plate design. ${ }^{1,2}$

The nominal design of the GTL-1 fuel miniplates was based on the common Reduced Enrichment for Research and Test Reactor (RERTR) miniplate designs for the Advanced Test Reactor (ATR) with modified thickness dimensions for both the cladding and fuel meat. The GTL-1 miniplates are comprised of ground $25 \%$ enriched (U-235) Silicide fuel powder clad in aluminum $\left(\mathrm{U}_{3} \mathrm{Si}_{2} / \mathrm{Al}\right){ }^{3}$

The GTL-1 test assembly holds four capsules (designated as A, B, C, and D) with A at the top of the assembly and D at the bottom. Each capsule has two levels with two plates per level for a total of four plate positions per capsule and 16 plate positions per assembly. Within each capsule the four plates are azimuthally designated as 1,2 in the upper level and 3, 4 in the lower level. The loading diagram for the GTL-1 experiment matrix is shown in Table 1. 
Table 1. GTL-1 experiment matrix.

\begin{tabular}{|c|c|c|}
\hline \multicolumn{3}{|c|}{ GTL-1 Matrix } \\
\hline \multirow{7}{*}{ 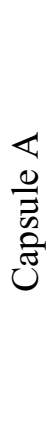 } & A1 & A2 \\
\hline & Standard Powder & Standard Powder \\
\hline & Standard Prefilm & Modified Prefilm \\
\hline & US06C & US15DM \\
\hline & A3 & A4 \\
\hline & Standard Powder & Standard Powder \\
\hline & Standard Prefilm & Standard Prefilm \\
\hline \multirow{8}{*}{ 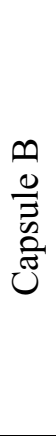 } & P1 & B2 \\
\hline & & \\
\hline & Standard Powder & No Fines Powder \\
\hline & Standard Prefilm & Standard Prefilm \\
\hline & US04GS & UN01FS \\
\hline & B3 & B4 \\
\hline & Standard Powder & Annealed Powder \\
\hline & $\begin{array}{c}\text { Standard Prefilm } \\
\text { US02FS }\end{array}$ & $\begin{array}{c}\text { Standard Prefilm } \\
\text { UA01FS }\end{array}$ \\
\hline \multirow{7}{*}{ 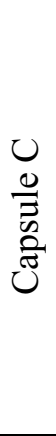 } & C1 & $\mathrm{C2}$ \\
\hline & Standard Powder & Standard Powder \\
\hline & Standard Prefilm & Modified Prefilm \\
\hline & US07FS & US16DM \\
\hline & $\mathrm{C3}$ & $\mathrm{C4}$ \\
\hline & Standard Powder & Standard Powder \\
\hline & $\begin{array}{c}\text { Standard Prefilm } \\
\text { US08CS }\end{array}$ & $\begin{array}{c}\text { Standard Prefilm } \\
\text { US14DS }\end{array}$ \\
\hline \multirow{7}{*}{ 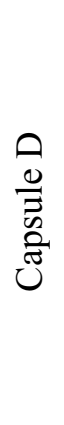 } & D1 & D2 \\
\hline & Standard Powder & No Fines Powder \\
\hline & Standard Prefilm & Standard Prefilm \\
\hline & D3 & D4 \\
\hline & Standard Powder & Standard Powder \\
\hline & Standard Prefilm & Modified Prefilm \\
\hline & US13GS & US17GM \\
\hline
\end{tabular}




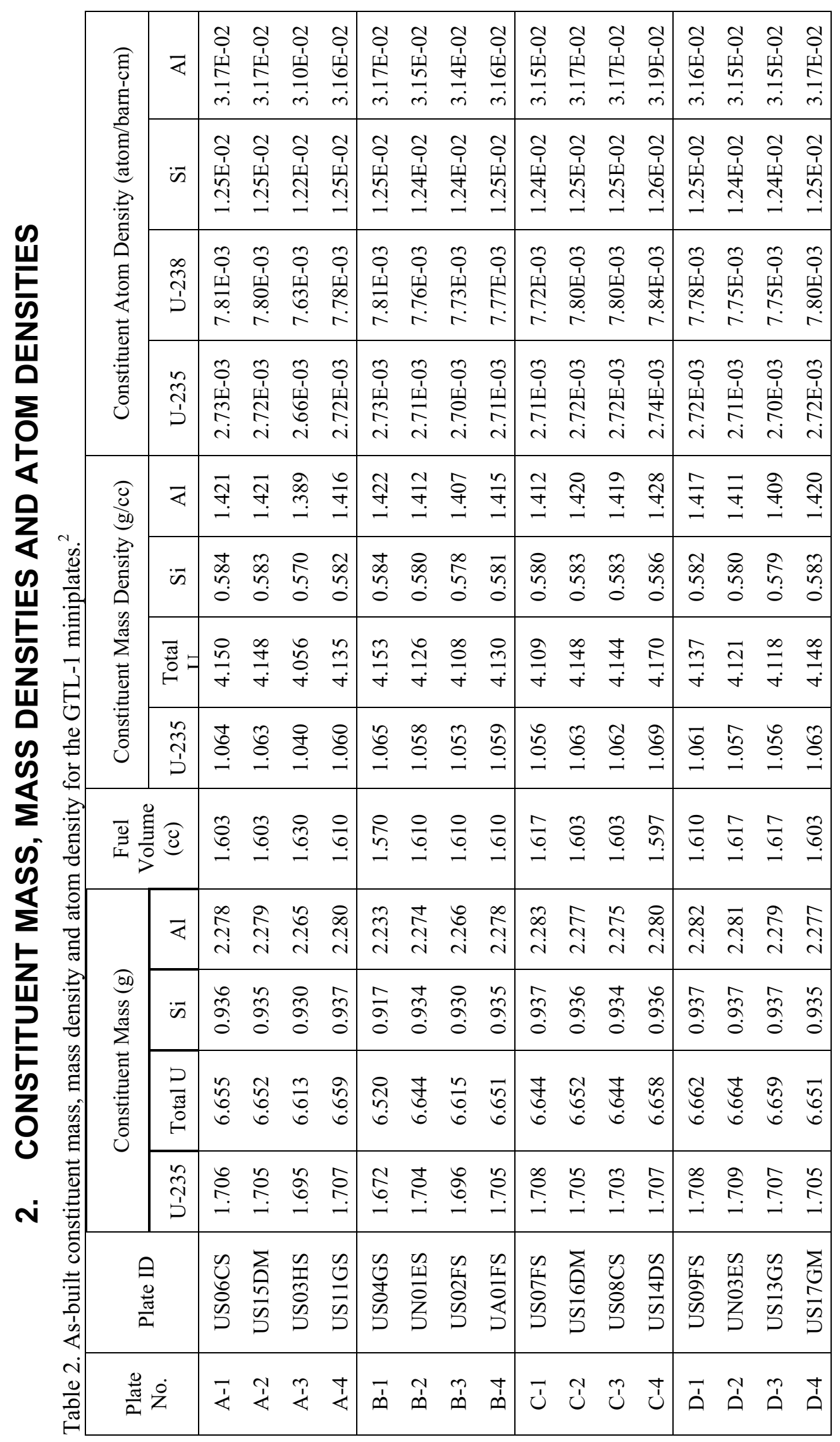




\section{EXPERIMENT HARDWARE}

The GTL-1 experiment hardware is similar to that of the RERTR miniplate experiments. The experiment hardware differs slightly from the RERTR miniplate experiments due to the thicker plates and the need for more coolant flow through the capsules. The list of drawings for the hardware used for the GTL-1 experiment is shown in Table 3 . $^{3}$

Table 3. GTL-1 miniplate experiment hardware.

Drawing

Number

DWG-600310

DWG-600418

DWG-600420

DWG-600447

DWG-600448

DWG-630233

DWG-630231

DWG-630225

DWG-630229

DWG-637210

DWG-637212

DWG-637213

DWG-637215
Drawing Title

ATR/ATRC BFFL (GTL-1) Miniplate Adapter Assemblies

ATR/ATRC BFFL (GTL-1) Miniplate SFT Adapter Back-up Assemblies

ATR BFFL (GTL-1) Miniplate Inner Basket Lift Assemblies and Details

ATR/ATRC BFFL (GTL-1) Miniplate Modified Large B-Position Basket Detail

ATR BFFL (GTL-1) Miniplate Irradiation Assembly

ATR Large B-Position Basket

ATR Top Spacer Assembly

ATR Upper Spacer Assembly

ATR Bottom Spacer Assembly

GTL Mini-Plate Capsule Assembly

Capsule. GTL

Capsule Cap

Fuel Plate, 0.040 in. Thick Fuel

The GTL-1 miniplate irradiation assembly, (see Figure 1) shows the main components of the test assembly, which include the bottom spacer, upper and top spacers, experiment capsules and basket. The bottom spacer elevates the experiment capsules to the correct location in the core. The upper and top spacers allow the operators to assure that the experiment is seated fully into the basket. All spacers are similar to the capsule design except the spacers do not have the grooves for the plates. The capsules hold the fuel plates; a capsule cap is welded onto the top of the capsule to keep the plates from sliding out during handling and irradiation. The fuel plate drawings plates (DWG-637215) and GTL-1 miniplate capsule assembly are shown in Figure 2 and Figure 3, respectively. Each capsule has a notch at the top and a groove at the bottom which allow the capsules to stack and align properly into the core. The basket holds the test assembly in the reactor during irradiation, the notches on the outer wall allow for bypass coolant flow to cool the outer wall. The basket has two guide bars on the inside wall to guide the assembly into the baskets. 


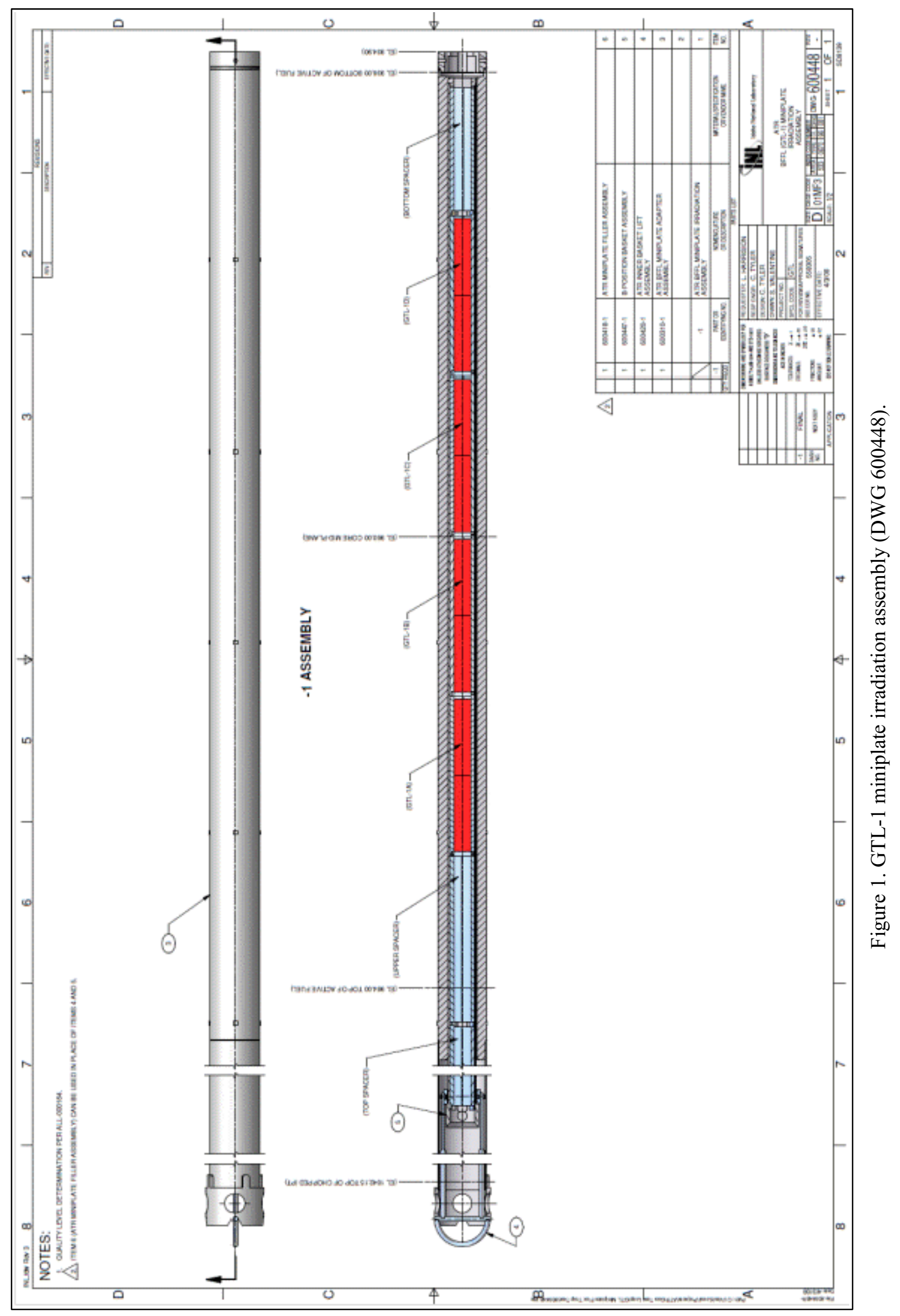




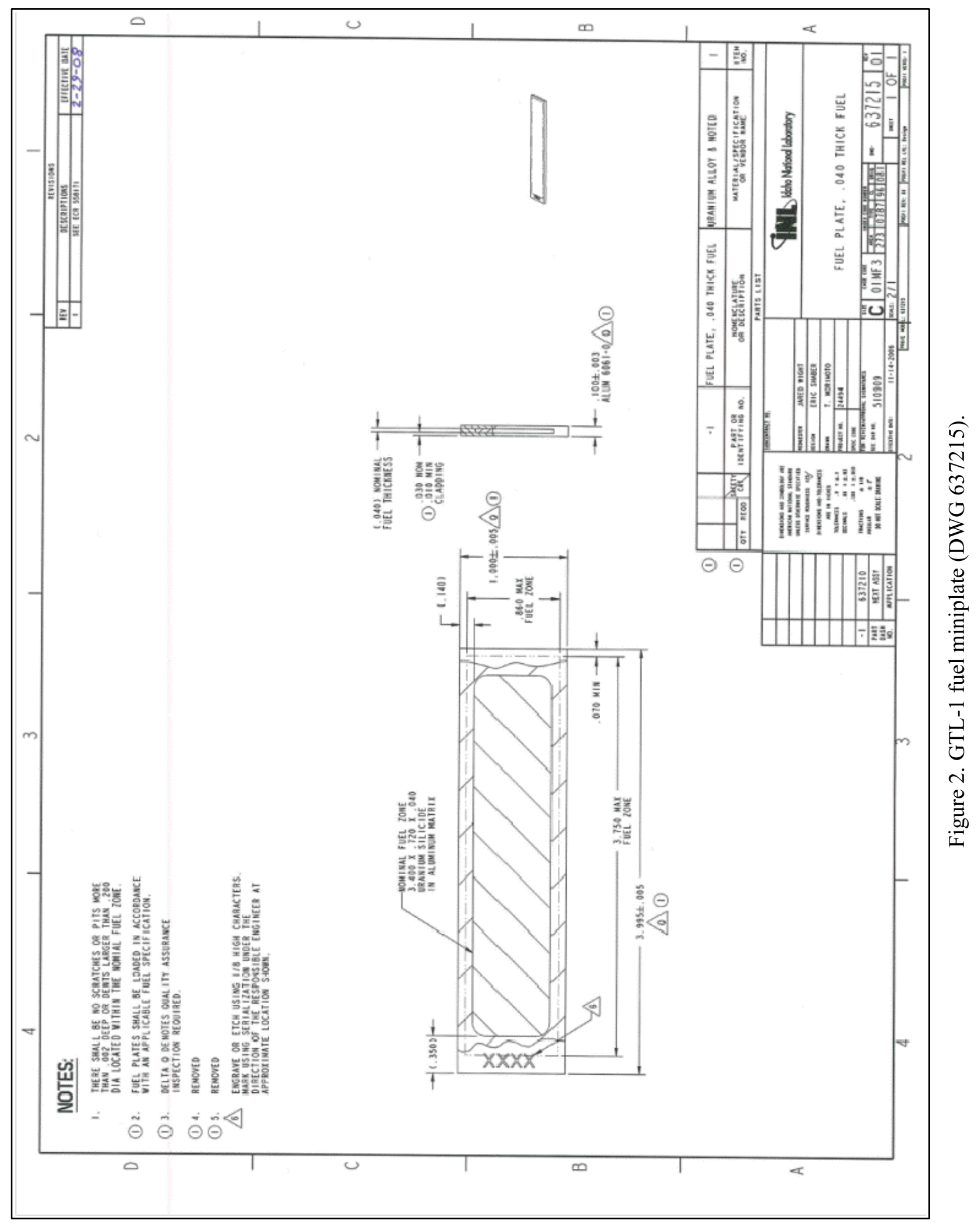




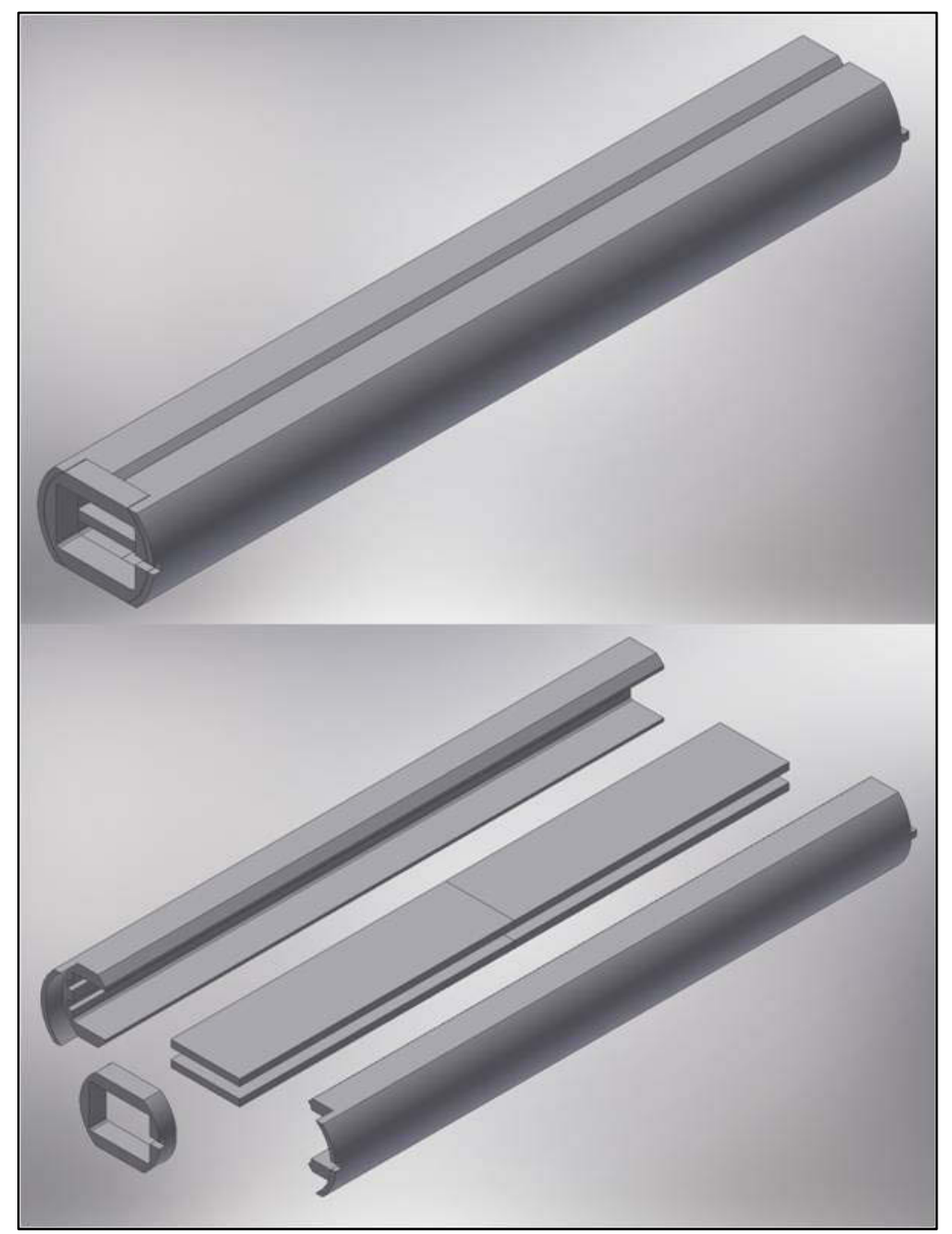

Figure 3. GTL-1 capsule assembly.

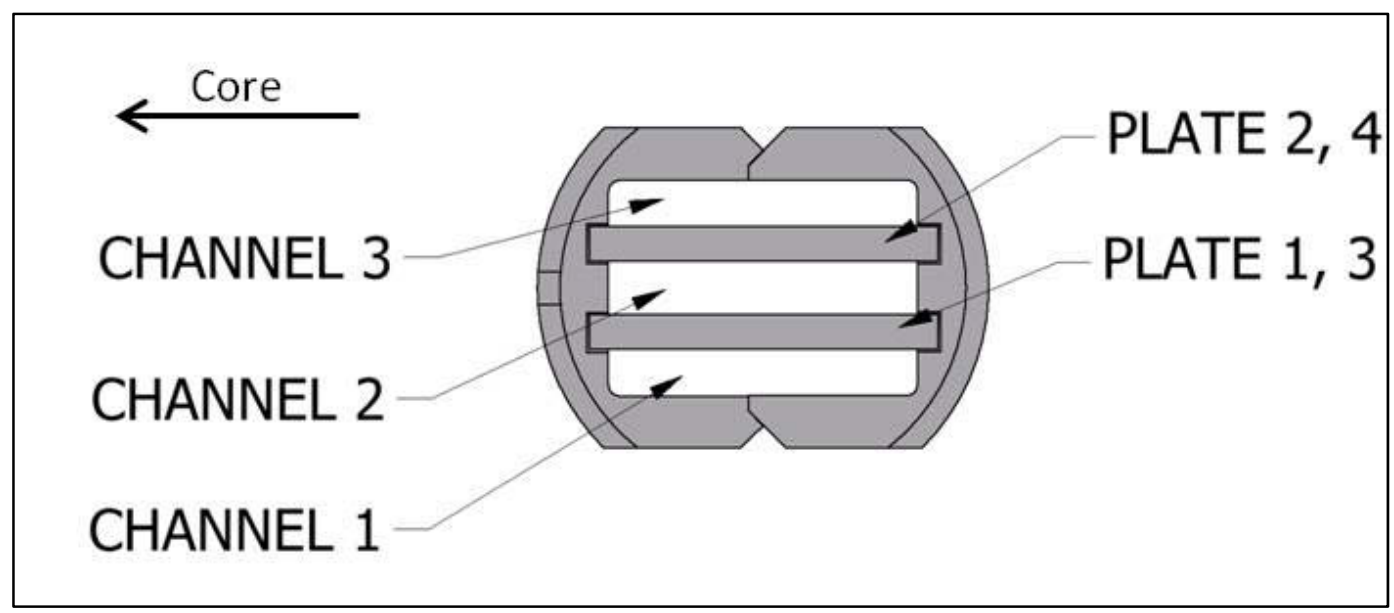

Figure 4. GTL-1 capsule cross section. 


\section{IRRADIATION HISTORY}

The GTL-1 test assembly was irradiated during ATR Cycle 143A in the South Flux Trap (SFT) position. The power of this position is the average of the $\mathrm{SW}, \mathrm{C}$, and $\mathrm{SE}$ lobe powers, $\mathrm{S}=(\mathrm{SW}+\mathrm{C}+\mathrm{SE})$ /3. Cycle 143A ran for 48.9 Effective Full Power Days (EFPD) at 25.4 MW. Cycle 143A began September 24, 2008 and ended December 6, 2008 with two cycle interruptions. The first cycle interruption was October 16, 2008-November 5, 2008 (20 days) and the second cycle interruption was from November 21, 2008-November 26, 2008 (5 days) for a total of 25 mid-cycle SCRAM decay days. This information is tabulated in Table 4.

Table 4. ATR irradiation history for the GTL-1 experiment. ${ }^{5}$

\begin{tabular}{|c|c|c|c|c|c|c|c|}
\hline $\begin{array}{c}\text { ATR } \\
\text { Cycle }\end{array}$ & $\begin{array}{c}\text { Test } \\
\text { ID }\end{array}$ & $\begin{array}{c}\text { Capsules } \\
\text { Irradiated }\end{array}$ & $\begin{array}{c}\text { Dates } \\
\text { Irradiated }\end{array}$ & $\begin{array}{c}\text { Cycle } \\
\text { EFPD }\end{array}$ & $\begin{array}{c}\text { Mid-Cycle } \\
\text { Scram Decay } \\
\text { Days }\end{array}$ & $\begin{array}{c}\text { Pouth Lobe } \\
\text { Pecay Days } \\
\text { Decle }\end{array}$ & $\begin{array}{c}\text { Source } \\
\text { Power (MW) }\end{array}$ \\
\hline 143A & GTL-1 & A,B,C,D & $\begin{array}{l}10 / 16 / 2008- \\
11 / 26 / 2008\end{array}$ & 48.9 & 25 & 17 & 25.4 \\
\hline
\end{tabular}

The Power history for Cycle 143A is obtained as an ATR Surveillance Report from the ATR Data Acquisition System (DAS). The plot of each lobe power on an hourly basis is shown in Figure 5.

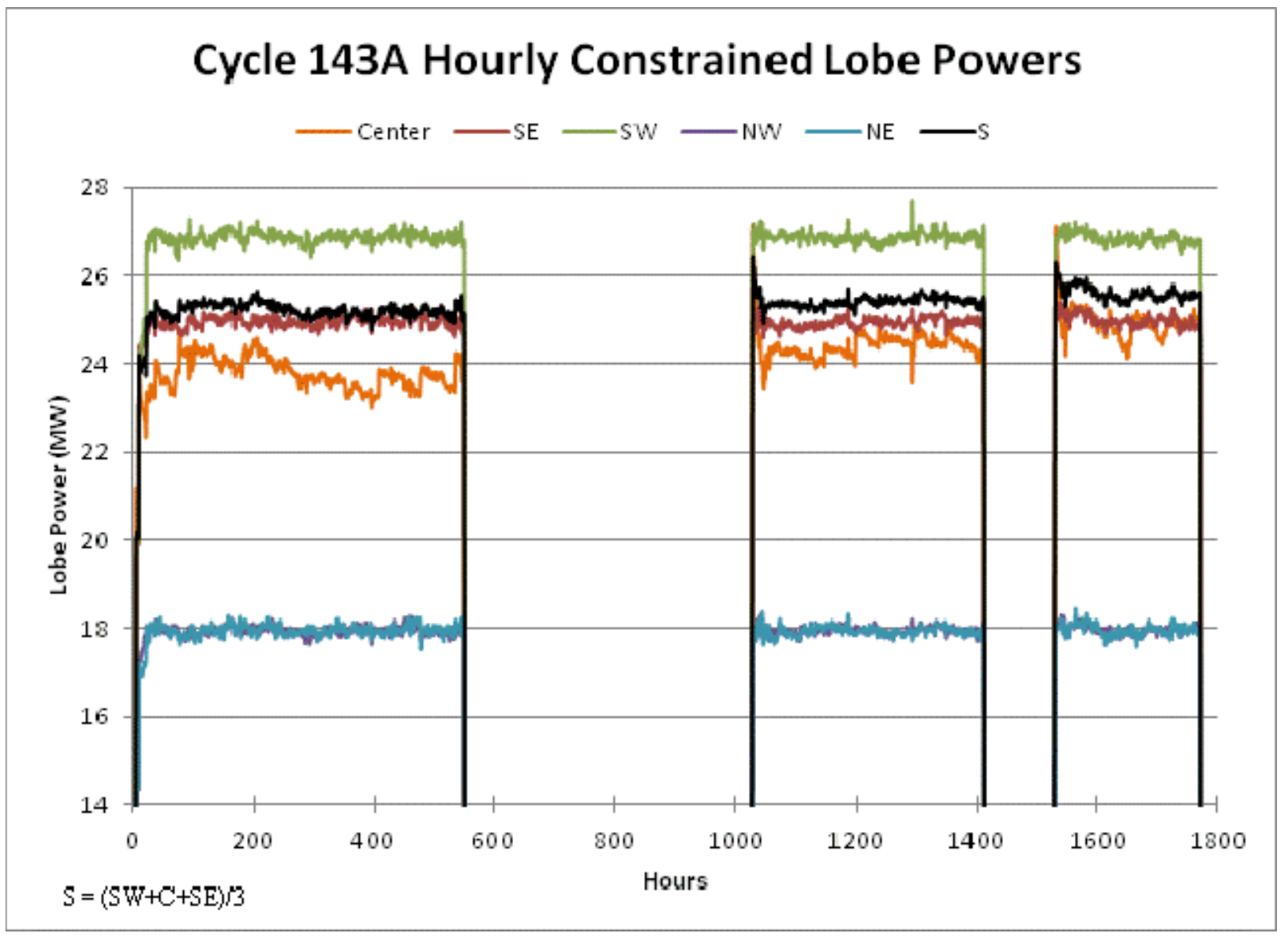

Figure 5. Hourly lobe power history for ATR Cycle 143A. 


\section{AS-RUN NUCLEAR ANALYSIS}

\subsection{Physics analysis}

The as-run calculations were performed using the irradiation history in Table 4 and the Monte $\underline{\text { Carlo }}$ N-Particle (MCNP) transport code. The calculated as-run fission heat rates and as-run U-235 burnup results for the fueled miniplates reported have an uncertainty band $(1 \sigma)$ of $2.5 \%{ }^{5}$ The time intervals used to calculate average plate power and burnup is shown in Table 5.

\begin{tabular}{cc}
\multicolumn{2}{c}{ Table 5. Cycle break down. } \\
\hline & $143 \mathrm{~A}$ \\
Time Interval & (Days) \\
\hline 01 & $1.0 \mathrm{e}-4$ \\
02 & 18.0 \\
03 & 18.0 \\
04 & 12.9 \\
05 & $1.0 \mathrm{e}-4$ \\
\hline EFPD & 48.9 \\
\hline
\end{tabular}

The MCNP model contained fuel meat densities based upon the measured volume of the fuel compact before undergoing the rolling fabrication process. Porosity within the fuel compact is reduced during the rolling fabrication process, thus increasing the actual density of the processed fuel meat. Therefore, the MCNP-modeled fuel meat densities are less than the actual processed fuel meat densities. To better represent the processed fuel meat densities, the rule of mixtures is used to calculate the density based upon the as-built masses and theoretical densities for $\mathrm{U}_{3} \mathrm{Si}_{2}$ and $\mathrm{Al}$ matrix. The rule of mixtures is given by equation (1). These corrected densities for the processed fuel meat were used to update the MCNPcalculated fission power density $(\mathrm{W} / \mathrm{cc})$ and heat flux $\left(\mathrm{W} / \mathrm{cm}^{2}\right)$. The as-built masses and calculated densities for the fuel compacts and the processed fuel meat are tabulated in Table 6 .

$$
\rho_{\text {processed fuel meat }}=\frac{\left(\text { mass }_{\text {fuel powder }}+\text { mass }_{\text {Al powder }}\right)}{\left(\frac{\text { mass }_{\text {fuel powder }}}{\rho_{\text {theoretical (fuel powder) }}}+\frac{\text { mass }_{\text {Al powder }}}{\left.\rho_{\text {theoretical (Al powder) }}\right)}\right)}
$$

The corrected fission heat rates at the beginning of cycle (BOC) are shown in Table 7. Table 8 through Table 10 contain the fission heat rates and U-235 burnup for 18 EFPD, 36 EFPD, and 48.9 EFPD, respectively. The individual plate power and burnup (fission density) are shown in Appendix A 
Table 6. GTL-1 fuel compact and processed fuel meat densities with the constituent as-built masses ${ }^{4}$.

\begin{tabular}{|c|c|c|c|c|c|}
\hline $\begin{array}{c}\text { Plate } \\
\text { Position }\end{array}$ & $\begin{array}{c}\text { Plate } \\
\text { ID }\end{array}$ & $\begin{array}{c}\text { Fuel Powder } \\
\text { (U \& Si) Mass } \\
(\mathrm{g})\end{array}$ & $\begin{array}{c}\text { Measured } \\
\text { Al Powder } \\
\text { Mass } \\
(\mathrm{g})\end{array}$ & $\begin{array}{c}\text { Calculated } \\
\text { Fuel Compact } \\
\text { Density } \\
(\mathrm{g} / \mathrm{cc})\end{array}$ & $\begin{array}{c}\text { Calculated } \\
\text { Processed } \\
\text { Fuel Meat } \\
\text { Density } \\
(\mathrm{g} / \mathrm{cc})\end{array}$ \\
\hline A-1 & US06CS & 7.591 & 2.278 & 6.16 & 6.732 \\
A-2 & US15DM & 7.587 & 2.279 & 6.15 & 6.730 \\
A-3 & US03HS & 7.543 & 2.265 & 6.02 & 6.731 \\
A-4 & US11GS & 7.596 & 2.280 & 6.13 & 6.732 \\
\hline B-1 & US04GS & 7.437 & 2.233 & 6.16 & 6.731 \\
B-2 & UN01ES & 7.579 & 2.274 & 6.12 & 6.733 \\
B-3 & US02FS & 7.545 & 2.266 & 6.09 & 6.730 \\
B-4 & UA01FS & 7.587 & 2.278 & 6.13 & 6.731 \\
\hline C-1 & US07FS & 7.601 & 2.283 & 6.10 & 6.730 \\
C-2 & US16DM & 7.588 & 2.277 & 6.15 & 6.732 \\
C-3 & US08CS & 7.579 & 2.275 & 6.14 & 6.732 \\
C-4 & US14DS & 7.595 & 2.280 & 6.19 & 6.731 \\
\hline D-1 & US09FS & 7.599 & 2.282 & 6.14 & 6.731 \\
D-2 & UN03ES & 7.602 & 2.281 & 6.11 & 6.733 \\
D-3 & US13GS & 7.596 & 2.279 & 6.11 & 6.733 \\
D-4 & US17GM & 7.586 & 2.277 & 6.15 & 6.732 \\
\hline
\end{tabular}


Table 7. BOC as-run GTL-1 calculated fission heating rates and U-235 burnup. ${ }^{5}$

\begin{tabular}{|c|c|c|c|c|c|}
\hline $\begin{array}{c}\text { Plate } \\
\text { No. }\end{array}$ & Plate ID & $\begin{array}{c}\text { Calculated } \\
\text { Processed Fuel } \\
\text { Meat Density } \\
\left(\mathrm{g} / \mathrm{cm}^{3}\right)\end{array}$ & $\begin{array}{c}\text { Fission } \\
\text { Heat } \\
\text { Rate } \\
(\mathrm{W} / \mathrm{g})\end{array}$ & $\begin{array}{c}\text { Fission } \\
\text { Power } \\
\text { Density } \\
\left(\mathrm{W} / \mathrm{cm}^{3}\right)\end{array}$ & $\begin{array}{c}\text { Heat } \\
\left(\mathrm{W} / \mathrm{cm}^{2}\right)\end{array}$ \\
A-2 & US06CS & 6.732 & 1231.82 & 8292.96 & 421.28 \\
A-3 & US15DM & 6.730 & 1236.26 & 8320.12 & 422.66 \\
A-4 & US11GS & 6.731 & 1535.49 & 10335.21 & 525.03 \\
B-1 & US04GS & 6.732 & 1531.27 & 10308.20 & 523.66 \\
B-2 & UN01ES & 6.733 & 1789.03 & 12042.03 & 611.74 \\
B-3 & US02FS & 6.730 & 1902.36 & 12803.77 & 650.43 \\
B-4 & UA01FS & 6.731 & 1899.59 & 12786.28 & 649.54 \\
\hline C-1 & US07FS & 6.730 & 1920.01 & 12922.22 & 656.45 \\
C-2 & US16DM & 6.732 & 1924.17 & 12954.30 & 658.08 \\
C-3 & US08CS & 6.732 & 1833.64 & 12343.52 & 627.05 \\
C-4 & US14DS & 6.731 & 1837.16 & 12366.81 & 628.23 \\
\hline D-1 & US09FS & 6.731 & 1636.48 & 11014.63 & 559.54 \\
D-2 & UN03ES & 6.733 & 1639.38 & 11037.31 & 560.70 \\
D-3 & US13GS & 6.733 & 1389.15 & 9352.92 & 475.13 \\
D-4 & US17GM & 6.732 & 1386.41 & 9333.00 & 474.12 \\
\hline
\end{tabular}

Table 8. As-Run GTL-1 calculated fission heat rates and U-235 burnup at 18 EFPD. ${ }^{5}$

\begin{tabular}{|c|c|c|c|c|c|c|c|}
\hline $\begin{array}{l}\text { Plate } \\
\text { No. }\end{array}$ & Plate ID & $\begin{array}{c}\text { Calculated } \\
\text { Processed Fuel } \\
\text { Meat Density } \\
\left(\mathrm{g} / \mathrm{cm}^{3}\right)\end{array}$ & $\begin{array}{c}\text { Fission } \\
\text { Heat } \\
\text { Rate } \\
(\mathrm{W} / \mathrm{g}) \\
\end{array}$ & $\begin{array}{l}\text { Fission } \\
\text { Power } \\
\text { Density } \\
\left(\mathrm{W} / \mathrm{cm}^{3}\right)\end{array}$ & $\begin{array}{l}\text { Fission } \\
\text { Heat } \\
\text { Flux } \\
\left(\mathrm{W} / \mathrm{cm}^{2}\right)\end{array}$ & $\begin{array}{c}\mathrm{U}-235 \\
\text { Burnup } \\
\Delta \mathrm{U}-235 / \mathrm{U}-235_{0} \\
(\%)\end{array}$ & $\begin{array}{c}\text { Fission } \\
\text { Density } \\
\left(\text { fission } / \mathrm{cm}^{3} \text { ) }\right.\end{array}$ \\
\hline A-1 & US06CS & 6.732 & 1153.75 & 7767.42 & 394.58 & $16.07 \%$ & $4.02 \mathrm{E}+20$ \\
\hline A-2 & US15DM & 6.730 & 1153.28 & 7761.65 & 394.29 & $16.12 \%$ & $4.03 E+20$ \\
\hline A-3 & US03HS & 6.731 & 1382.52 & 9305.58 & 472.72 & $19.56 \%$ & $4.89 \mathrm{E}+20$ \\
\hline A-4 & US11GS & 6.732 & 1383.52 & 9313.57 & 473.13 & $19.55 \%$ & $4.98 \mathrm{E}+20$ \\
\hline B-1 & US04GS & 6.731 & 1553.58 & 10457.23 & 531.23 & $22.43 \%$ & $5.84 \mathrm{E}+20$ \\
\hline B-2 & UN01ES & 6.733 & 1557.52 & 10486.36 & 532.71 & $22.43 \%$ & $5.80 \mathrm{E}+20$ \\
\hline B-3 & US02FS & 6.730 & 1623.45 & 10926.58 & 555.07 & $23.64 \%$ & $6.14 \mathrm{E}+20$ \\
\hline B-4 & UA01FS & 6.731 & 1622.89 & 10923.83 & 554.93 & $23.63 \%$ & $6.17 \mathrm{E}+20$ \\
\hline $\mathrm{C}-1$ & US07FS & 6.730 & 1634.59 & 11001.25 & 558.86 & $23.84 \%$ & $6.21 \mathrm{E}+20$ \\
\hline $\mathrm{C}-2$ & US16DM & 6.732 & 1633.82 & 10999.51 & 558.78 & $23.90 \%$ & $6.27 \mathrm{E}+20$ \\
\hline $\mathrm{C}-3$ & US08CS & 6.732 & 1581.58 & 10646.69 & 540.85 & $22.93 \%$ & $5.97 \mathrm{E}+20$ \\
\hline C-4 & US14DS & 6.731 & 1583.31 & 10658.03 & 541.43 & $22.96 \%$ & $6.02 \mathrm{E}+20$ \\
\hline D-1 & US09FS & 6.731 & 1448.00 & 9746.03 & 495.10 & $20.75 \%$ & $5.32 \mathrm{E}+20$ \\
\hline D-2 & UN03ES & 6.733 & 1450.39 & 9764.90 & 496.06 & $20.75 \%$ & $5.31 \mathrm{E}+20$ \\
\hline D-3 & US13GS & 6.733 & 1271.45 & 8560.41 & 434.87 & $17.89 \%$ & $4.50 \mathrm{E}+20$ \\
\hline D-4 & US17GM & 6.732 & 1266.08 & 8523.02 & 432.97 & $17.88 \%$ & $4.52 \mathrm{E}+20$ \\
\hline
\end{tabular}


Table 9. As-Run GTL-1 calculated fission heat rates and U-235 burnup at 36 EFPD. ${ }^{5}$

\begin{tabular}{|c|c|c|c|c|c|c|c|}
\hline $\begin{array}{l}\text { Plate } \\
\text { No. }\end{array}$ & Plate ID & $\begin{array}{c}\text { Calculated } \\
\text { Processed Fuel } \\
\text { Meat Density } \\
\left(\mathrm{g} / \mathrm{cm}^{3}\right)\end{array}$ & $\begin{array}{c}\text { Fission } \\
\text { Heat } \\
\text { Rate } \\
(\mathrm{W} / \mathrm{g}) \\
\end{array}$ & $\begin{array}{l}\text { Fission } \\
\text { Power } \\
\text { Density } \\
\left(\mathrm{W} / \mathrm{cm}^{3}\right)\end{array}$ & $\begin{array}{l}\text { Fission } \\
\text { Heat } \\
\text { Flux } \\
\left(\mathrm{W} / \mathrm{cm}^{2}\right)\end{array}$ & $\begin{array}{c}\mathrm{U}-235 \\
\text { Burnup } \\
\Delta \mathrm{U}-235 / \mathrm{U}-235_{0} \\
(\%)\end{array}$ & $\begin{array}{c}\text { Fission } \\
\text { Density } \\
\left(\text { fission } / \mathrm{cm}^{3}\right)\end{array}$ \\
\hline A-1 & US06CS & 6.732 & 1079.66 & 7268.57 & 369.24 & $30.63 \%$ & $7.74 \mathrm{E}+20$ \\
\hline A-2 & US15DM & 6.730 & 1086.55 & 7312.52 & 371.48 & $30.69 \%$ & $7.75 \mathrm{E}+20$ \\
\hline A-3 & US03HS & 6.731 & 1253.13 & 8434.62 & 428.48 & $36.52 \%$ & $9.23 \mathrm{E}+20$ \\
\hline A-4 & US11GS & 6.732 & 1250.91 & 8420.86 & 427.78 & $36.49 \%$ & $9.40 \mathrm{E}+20$ \\
\hline B-1 & US04GS & 6.731 & 1353.10 & 9107.78 & 462.68 & $41.00 \%$ & $1.08 \mathrm{E}+21$ \\
\hline B-2 & UN01ES & 6.733 & 1353.63 & 9113.58 & 462.97 & $41.02 \%$ & $1.08 \mathrm{E}+21$ \\
\hline B-3 & US02FS & 6.730 & 1393.90 & 9381.58 & 476.58 & $42.87 \%$ & $1.13 \mathrm{E}+21$ \\
\hline B-4 & UA01FS & 6.731 & 1391.82 & 9368.43 & 475.92 & $42.87 \%$ & $1.13 \mathrm{E}+21$ \\
\hline $\mathrm{C}-1$ & US07FS & 6.730 & 1404.18 & 9450.54 & 480.09 & $43.13 \%$ & $1.14 \mathrm{E}+21$ \\
\hline $\mathrm{C}-2$ & US16DM & 6.732 & 1399.23 & 9420.16 & 478.54 & $43.21 \%$ & $1.15 \mathrm{E}+21$ \\
\hline $\mathrm{C}-3$ & US08CS & 6.732 & 1372.99 & 9242.55 & 469.52 & $41.79 \%$ & $1.10 \mathrm{E}+21$ \\
\hline$C-4$ & US14DS & 6.731 & 1374.37 & 9251.54 & 469.98 & $41.80 \%$ & $1.11 \mathrm{E}+21$ \\
\hline D-1 & US09FS & 6.731 & 1298.40 & 8739.11 & 443.95 & $38.30 \%$ & $9.95 \mathrm{E}+20$ \\
\hline $\mathrm{D}-2$ & UN03ES & 6.733 & 1303.77 & 8777.77 & 445.91 & $38.37 \%$ & $9.92 \mathrm{E}+20$ \\
\hline D-3 & US13GS & 6.733 & 1177.98 & 7931.12 & 402.90 & $33.72 \%$ & $8.56 \mathrm{E}+20$ \\
\hline D-4 & US17GM & 6.732 & 1179.01 & 7936.87 & 403.19 & $33.66 \%$ & $8.59 \mathrm{E}+20$ \\
\hline
\end{tabular}

Table 10. EOC as-run GTL-1 calculated fission heat rates and U-235 burnup (48.9 EFPD). ${ }^{5}$

\begin{tabular}{|c|c|c|c|c|c|c|c|}
\hline $\begin{array}{c}\text { Plate } \\
\text { No. }\end{array}$ & Plate ID & $\begin{array}{c}\text { Calculated } \\
\text { Processed Fuel } \\
\text { Meat Density } \\
\left(\mathrm{g} / \mathrm{cm}^{3}\right)\end{array}$ & $\begin{array}{c}\text { Fission } \\
\text { Heat } \\
\text { Rate } \\
(\mathrm{W} / \mathrm{g})\end{array}$ & $\begin{array}{l}\text { Fission } \\
\text { Power } \\
\text { Density } \\
\left(\mathrm{W} / \mathrm{cm}^{3}\right)\end{array}$ & $\begin{array}{c}\text { Fission } \\
\text { Heat } \\
\text { Flux } \\
\left(\mathrm{W} / \mathrm{cm}^{2}\right)\end{array}$ & $\begin{array}{c}\mathrm{U}-235 \\
\text { Burnup } \\
\Delta \mathrm{U}-235 / \mathrm{U}-235_{0} \\
(\%)\end{array}$ & $\begin{array}{c}\text { Fission } \\
\text { Density } \\
\left(\text { fission } / \mathrm{cm}^{3}\right)\end{array}$ \\
\hline A-1 & US06CS & 6.732 & 997.36 & 6714.51 & 341.10 & $40.28 \%$ & $1.02 \mathrm{E}+21$ \\
\hline A-2 & US15DM & 6.730 & 1001.35 & 6739.18 & 342.35 & $40.38 \%$ & $1.02 \mathrm{E}+21$ \\
\hline A-3 & US03HS & 6.731 & 1128.53 & 7595.96 & 385.87 & $47.33 \%$ & $1.20 \mathrm{E}+21$ \\
\hline A-4 & US11GS & 6.732 & 1128.35 & 7595.80 & 385.87 & $47.31 \%$ & $1.22 \mathrm{E}+21$ \\
\hline B-1 & US04GS & 6.731 & 1196.70 & 8055.02 & 409.19 & $52.36 \%$ & $1.38 \mathrm{E}+21$ \\
\hline B-2 & UN01ES & 6.733 & 1195.25 & 8047.29 & 408.80 & $52.38 \%$ & $1.38 \mathrm{E}+21$ \\
\hline B-3 & US02FS & 6.730 & 1221.37 & 8220.41 & 417.60 & $54.46 \%$ & $1.44 \mathrm{E}+21$ \\
\hline B-4 & UA01FS & 6.731 & 1219.28 & 8207.10 & 416.92 & $54.44 \%$ & $1.44 \mathrm{E}+21$ \\
\hline $\mathrm{C}-1$ & US07FS & 6.730 & 1227.20 & 8259.42 & 419.58 & $54.77 \%$ & $1.45 \mathrm{E}+21$ \\
\hline $\mathrm{C}-2$ & US16DM & 6.732 & 1225.04 & 8247.47 & 418.97 & $54.81 \%$ & $1.46 \mathrm{E}+21$ \\
\hline $\mathrm{C}-3$ & US08CS & 6.732 & 1206.66 & 8122.84 & 412.64 & $53.29 \%$ & $1.41 \mathrm{E}+21$ \\
\hline$C-4$ & US14DS & 6.731 & 1208.91 & 8137.79 & 413.40 & $53.30 \%$ & $1.42 \mathrm{E}+21$ \\
\hline D-1 & US09FS & 6.731 & 1161.59 & 7818.27 & 397.17 & $49.37 \%$ & $1.29 \mathrm{E}+21$ \\
\hline D-2 & UN03ES & 6.733 & 1164.23 & 7838.28 & 398.18 & $49.48 \%$ & $1.28 \mathrm{E}+21$ \\
\hline D-3 & US13GS & 6.733 & 1071.93 & 7217.11 & 366.63 & $44.07 \%$ & $1.12 \mathrm{E}+21$ \\
\hline D-4 & US17GM & 6.732 & 1071.78 & 7215.03 & 366.52 & $44.02 \%$ & $1.13 \mathrm{E}+21$ \\
\hline
\end{tabular}




\subsection{Gradients}

The MCNP-calculated power gradients in the transverse and axial directions are represented by the fission rate local-to-average ratios (L2ARs) as a function of position for eight fuel plates (one column of fuel plates [i.e., A-1, A-3, B-1, B-3, C-1, C-3, D-1, and D-3]). The calculated gradients may be used to represent the gradient for either column of fuel plates. The L2AR fission power gradients in the transverse direction for the GTL-1 fueled miniplates are shown in Table 11 and plotted in Figure 6. The L2AR

fission power gradients in the axial direction for the GTL-1 fueled miniplates are shown in Table 12 and are plotted in Figure $7 .^{5}$ 


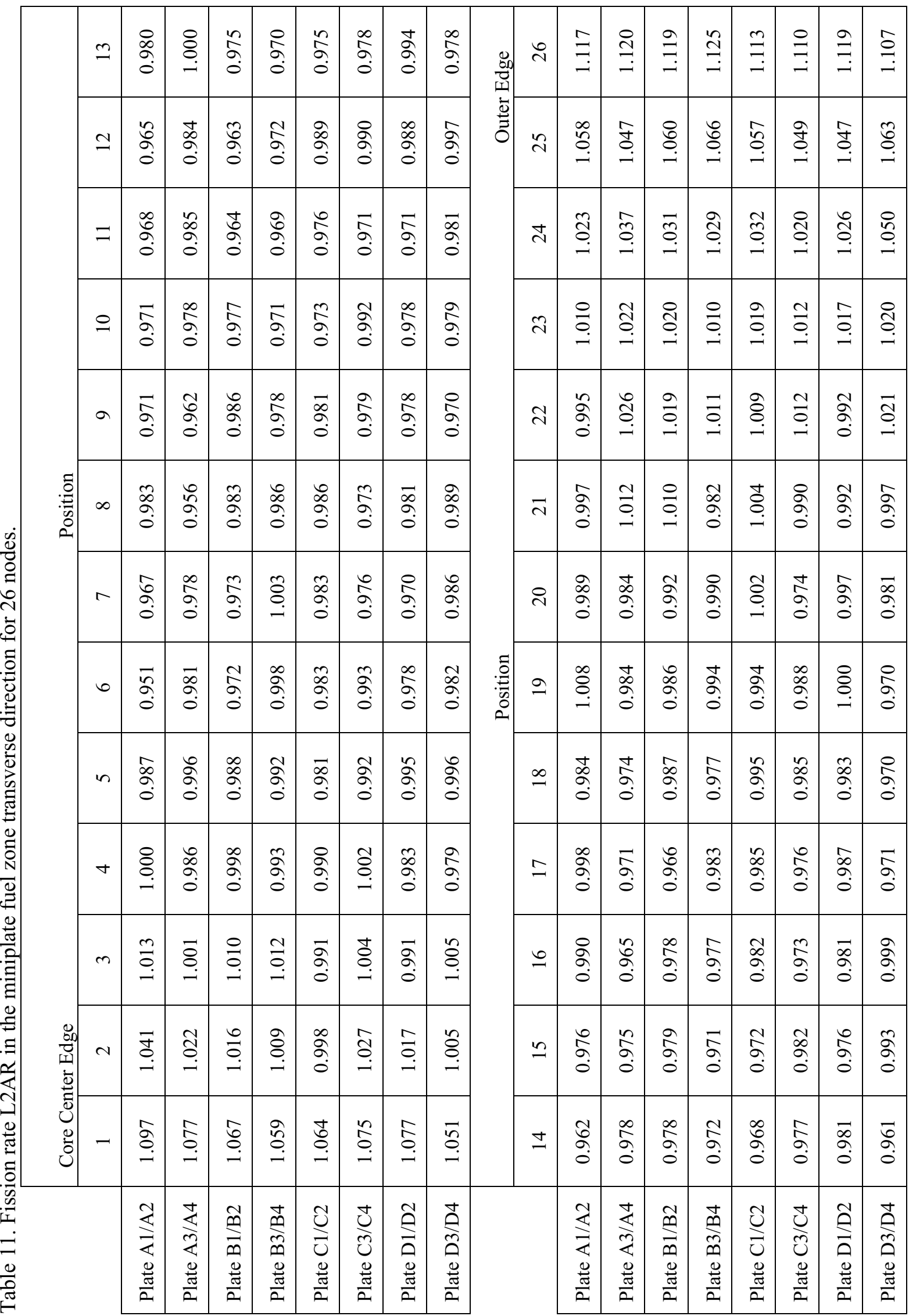




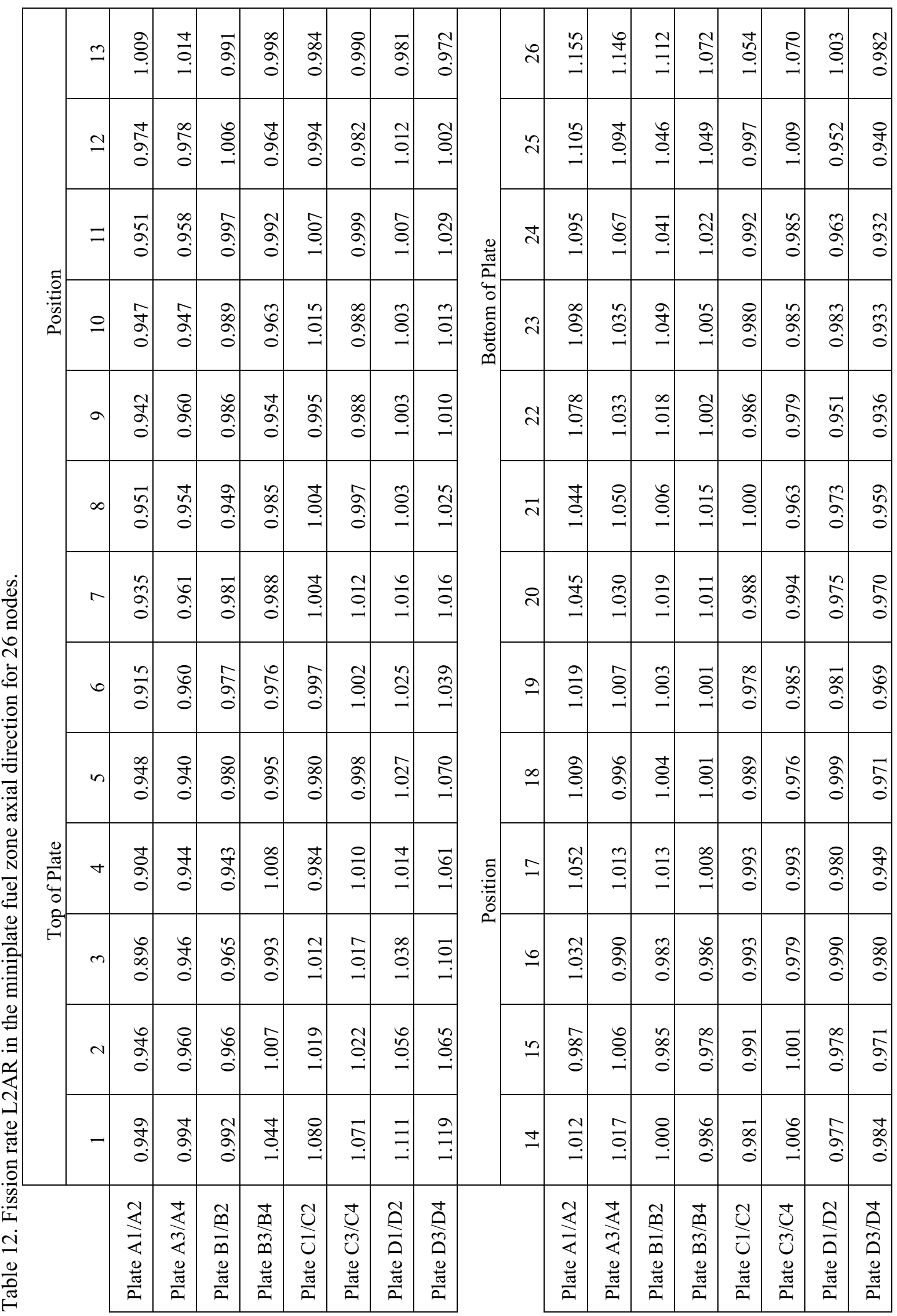




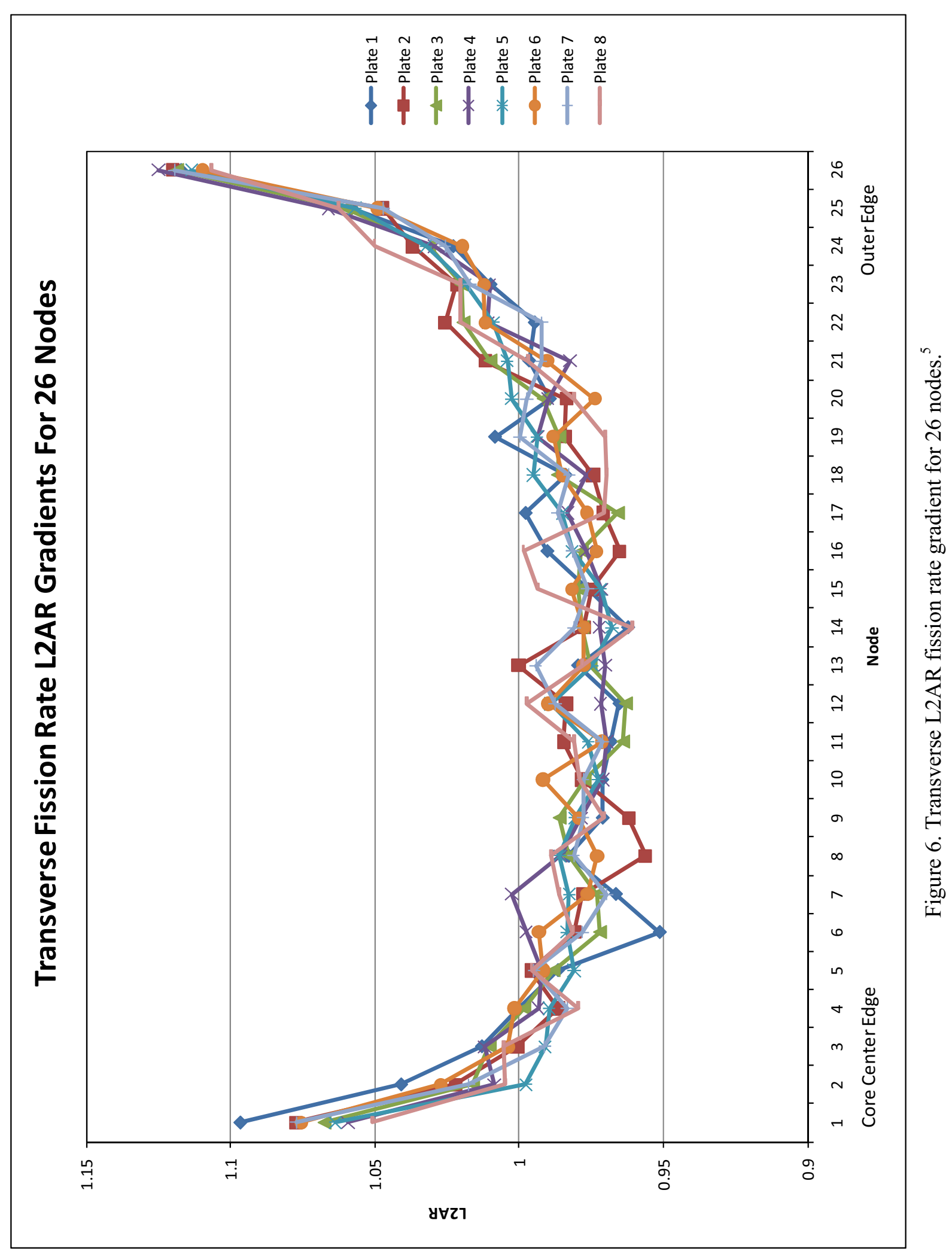




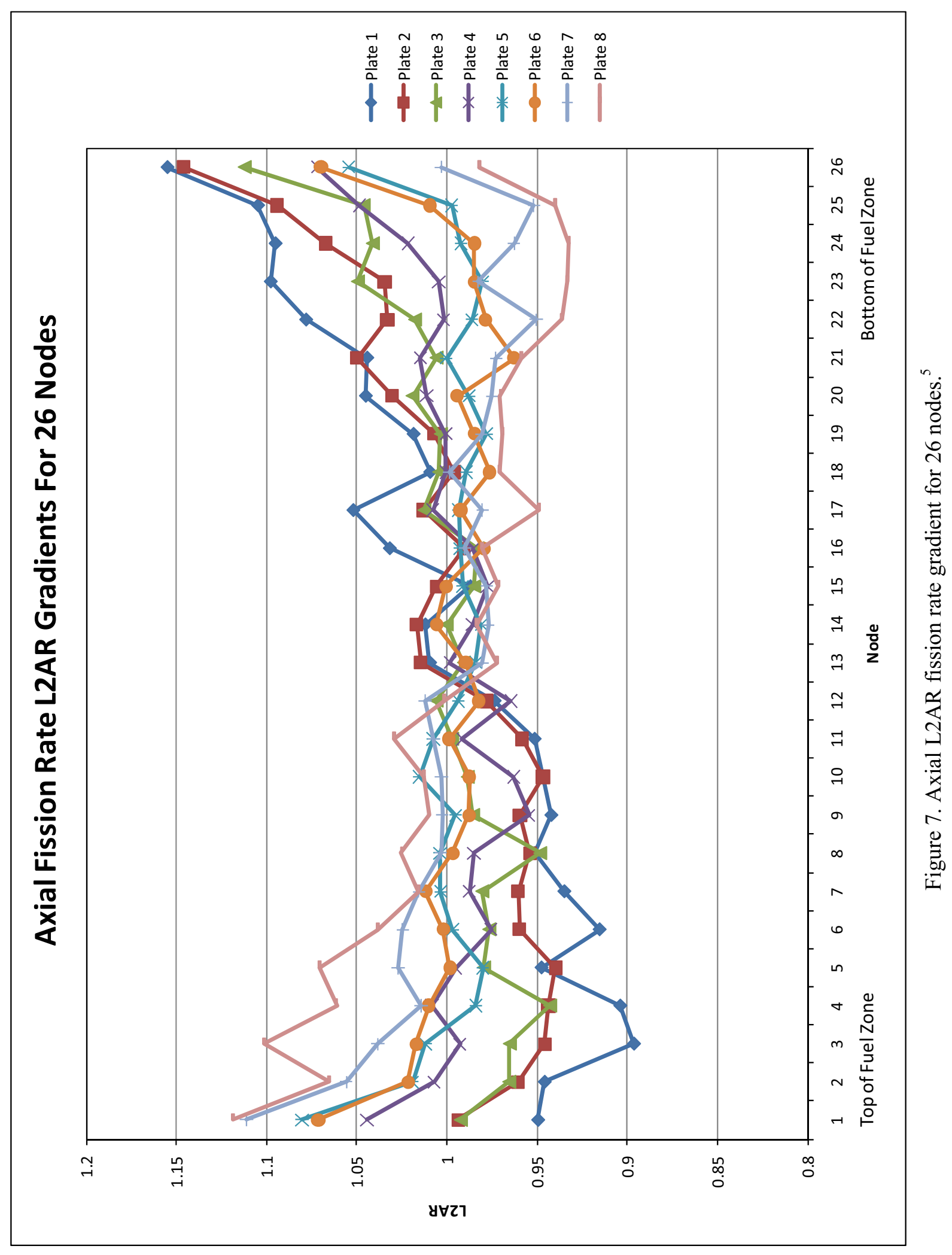




\section{HYDRAULIC TESTING}

Flow tests were performed to characterize the test vehicle designed to irradiate miniplates for the GTL project. The vehicle had been used for multiple flow tests for the RERTR program irradiation tests. The results of the flow tests will be used to generate high confidence estimates of the coolant flow rate required to accurately calculate the miniplate temperatures during irradiation.

The test apparatus was designed and constructed to simulate the ATR Large-B position and flow conditions. The test vehicle was fabricated such that the orifice plate could be easily interchanged (screwed on instead of welded on the test vehicle). Three orifice plate sizes were tested along with no orifice plate and with the basket exit blocked (to measure bypass flow). The results of this test are shown in Table $13{ }^{6}$

Table 13. Loss coefficients for the GTL-1 irradiation test vehicle components. ${ }^{6}$

\begin{tabular}{cccc}
\hline $\begin{array}{c}\text { Orifice Diameter } \\
(\mathrm{mm})\end{array}$ & $\begin{array}{c}\mathrm{K} / \mathrm{A}^{2} \\
\left(1 / \mathrm{m}^{4}\right)\end{array}$ & $\begin{array}{c}\text { ATR Coolant Flow } \\
\text { Rate } \\
(\mathrm{GPM})\end{array}$ & $\begin{array}{c}\text { ATR Coolant } \\
\text { Velocity (ft/sec) }\end{array}$ \\
\hline Bypass & $2.8414 \mathrm{E} 8$ & 30.1 & - \\
Open & $8.3028 \mathrm{E} 7$ & 55.6 & 47.8 \\
9 & $7.5754 \mathrm{E} 8$ & 17.5 & 15.1 \\
8 & $1.8588 \mathrm{E} 9$ & 11.5 & 9.9 \\
7 & $2.7422 \mathrm{E} 9$ & 9.5 & 8.2 \\
\hline
\end{tabular}

Even though the GTL-1 experiment was irradiated in the SFT, the design parameters for the target coolant flow rate were still applicable. An insert mimicking the Large -B position was put into the SFT for irradiation of the GTL-1 experiment. 


\section{AS-RUN THERMAL ANALYSIS}

The as-run thermal analysis was performed using the MCNP-generated heat flux calculations, the nominal coolant flow rate and as-built fuel meat thickness. The heat transfer correlation used to calculate the plate surface temperature and the coolant channel temperatures was the Petukhov heat transfer correlation ${ }^{7}$ (see equation (2)).

$$
\mathrm{Nu}=\frac{\mathrm{hD}}{\mathrm{k}}=\frac{\left(\mathrm{f}_{\mathrm{F}} / 2\right) \operatorname{RePr}}{1.07+12.7\left(\mathrm{f}_{\mathrm{F}} / 2\right)^{1 / 2}\left(\operatorname{Pr}^{2 / 3}-1\right)}\left(\frac{\mu}{\mu_{\mathrm{w}}}\right)^{0.14}
$$

Where $\mathrm{Nu}$ is the Nusselt number, $\mathrm{h}$ is the heat transfer coefficient, $\mathrm{D}$ is the hydraulic diameter, $\mathrm{k}$ is the thermal conductivity, $\mathrm{Re}$ is the Reynolds number, $\mathrm{Pr}$ is the Prandlt number, $\mathrm{f}_{\mathrm{F}}$ is the Fanning friction factor $^{7}$ (see equation (3)), $\mu$ is the fluid dynamic viscosity at the bulk temperature and $\mu_{\mathrm{w}}$ is the fluid dynamic viscosity at the wall temperature.

$$
f_{F}=\left(3.64 \log _{10} \operatorname{Re}-3.28\right)^{-2}
$$

The coolant temperature along the fuel zone of each plate (equation (4)) was analyzed at the three flow channels in the test assembly, zero mixing between capsules was assumed for these calculations, the plate surface temperature (equation (5)) was analyzed for the front and back of the plates.

$$
\mathbf{T}_{\text {cool }}=\frac{\mathbf{q}^{\prime \prime} \mathbf{A}}{\rho \mathbf{c}_{\mathrm{p}} \mathbf{Q}}+\mathbf{T}_{\mathrm{in}}
$$

Where q" is the MCNP-calculated heat flux, A is the cross sectional area of the coolant channel, $\rho$ is the density of the fluid, $c_{p}$ is fluid specific heat, $Q$ is the coolant volumetric flow rate through the given channel and $\mathrm{T}_{\text {in }}$ is the coolant temperature at the axial location that precedes the current axial location.

$$
\mathbf{T}_{\text {surface }}=\frac{\mathbf{q}^{\prime \prime}}{\mathbf{h}}+\mathbf{T}_{\text {cool }}
$$




\subsection{Coolant Temperature as a Function of Location}

The coolant temperature was analyzed at the three flow channels in the test assembly, with channel 1 at the left of the assembly; channel 2 in between the plates and channel 3 at the right of the assembly (see Figure 4). The coolant temperature was plotted as a function of location along the test assembly at each time step. These plots are shown in Figure 8 through Figure 10.

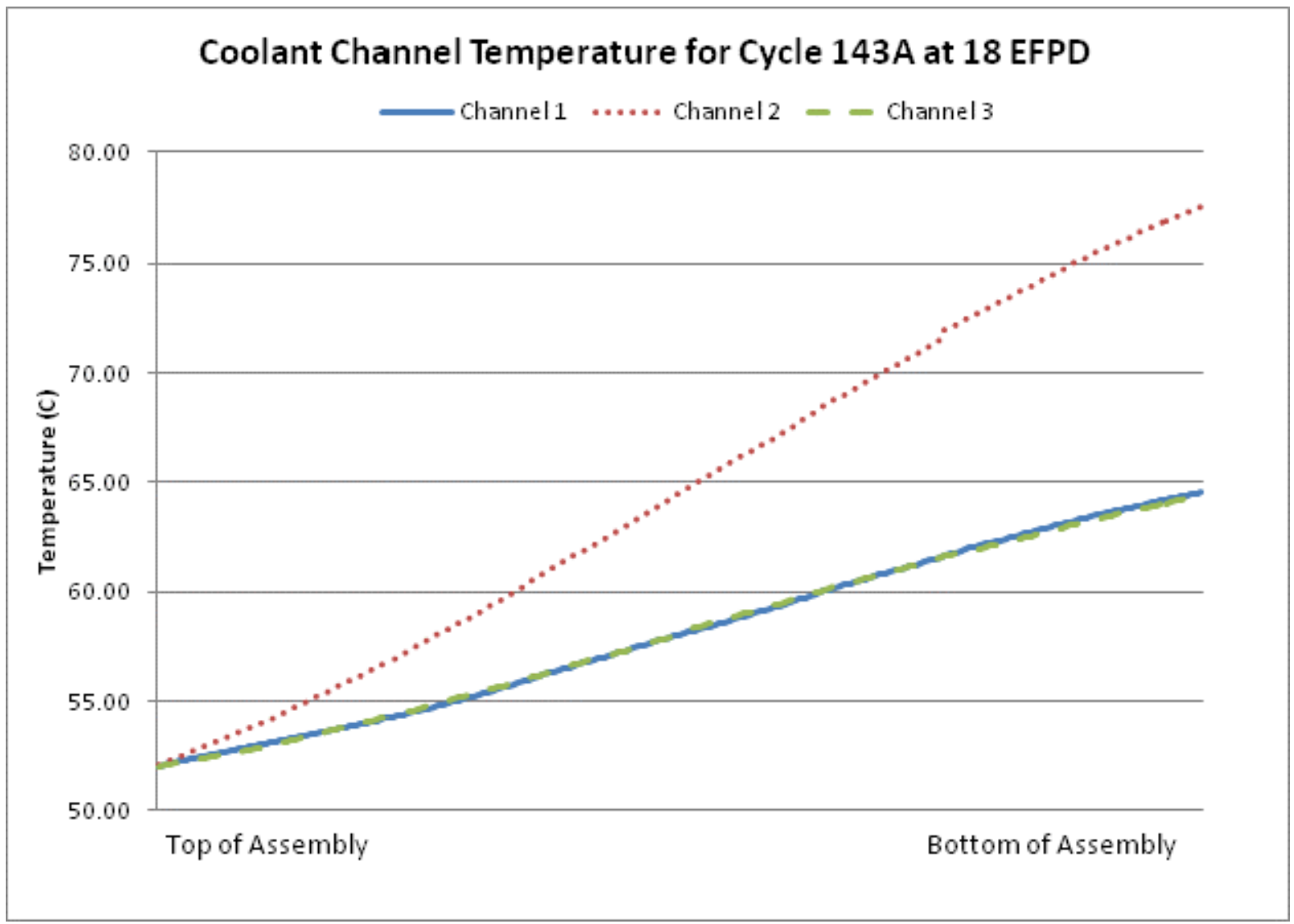

Figure 8. GTL-1 coolant channel temperature along the test assembly for Cycle 143A at 18 EFPD. 


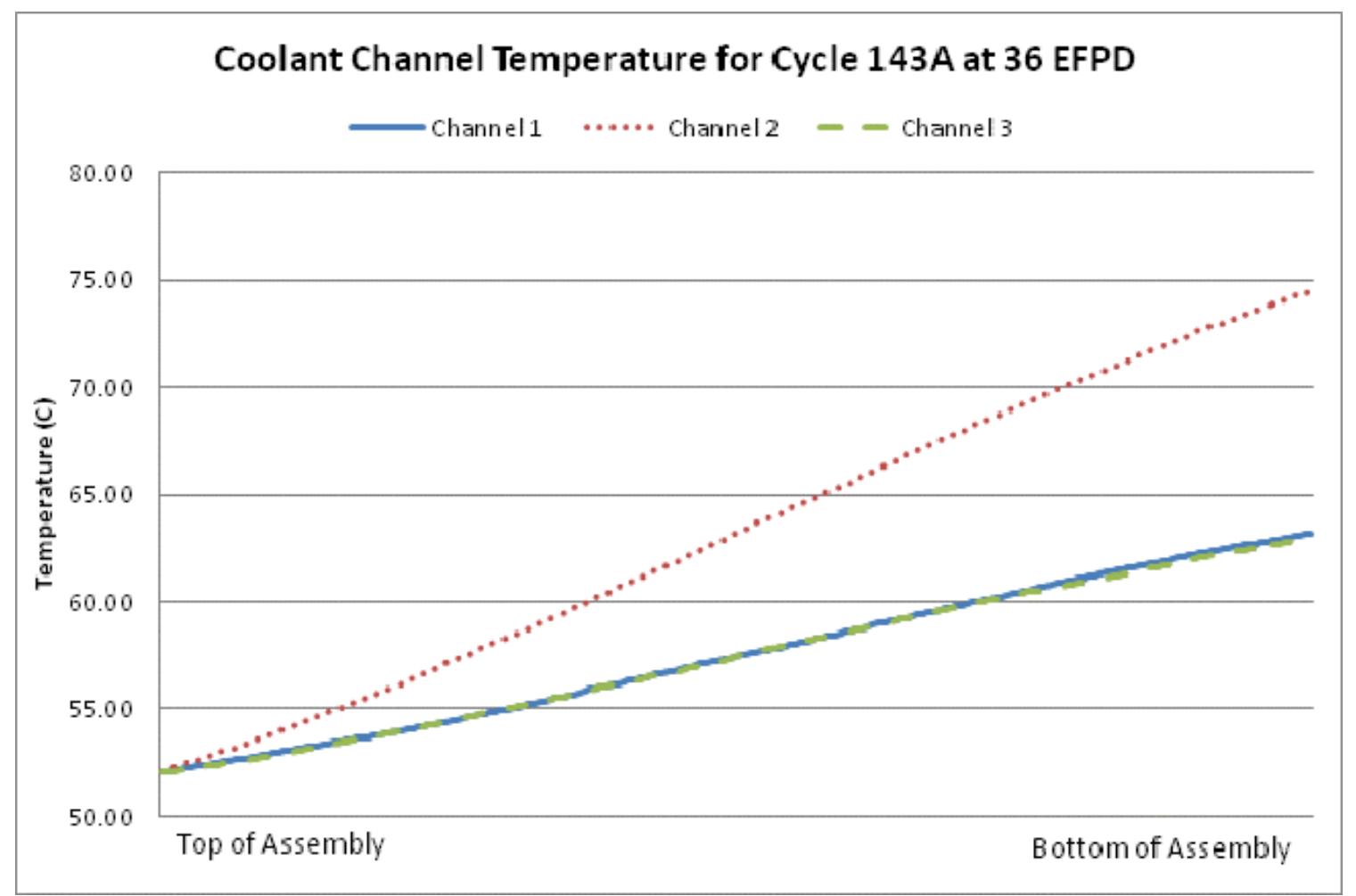

Figure 9. GTL-1 coolant channel temperature along the test assembly for Cycle 143A at 36 EFPD.

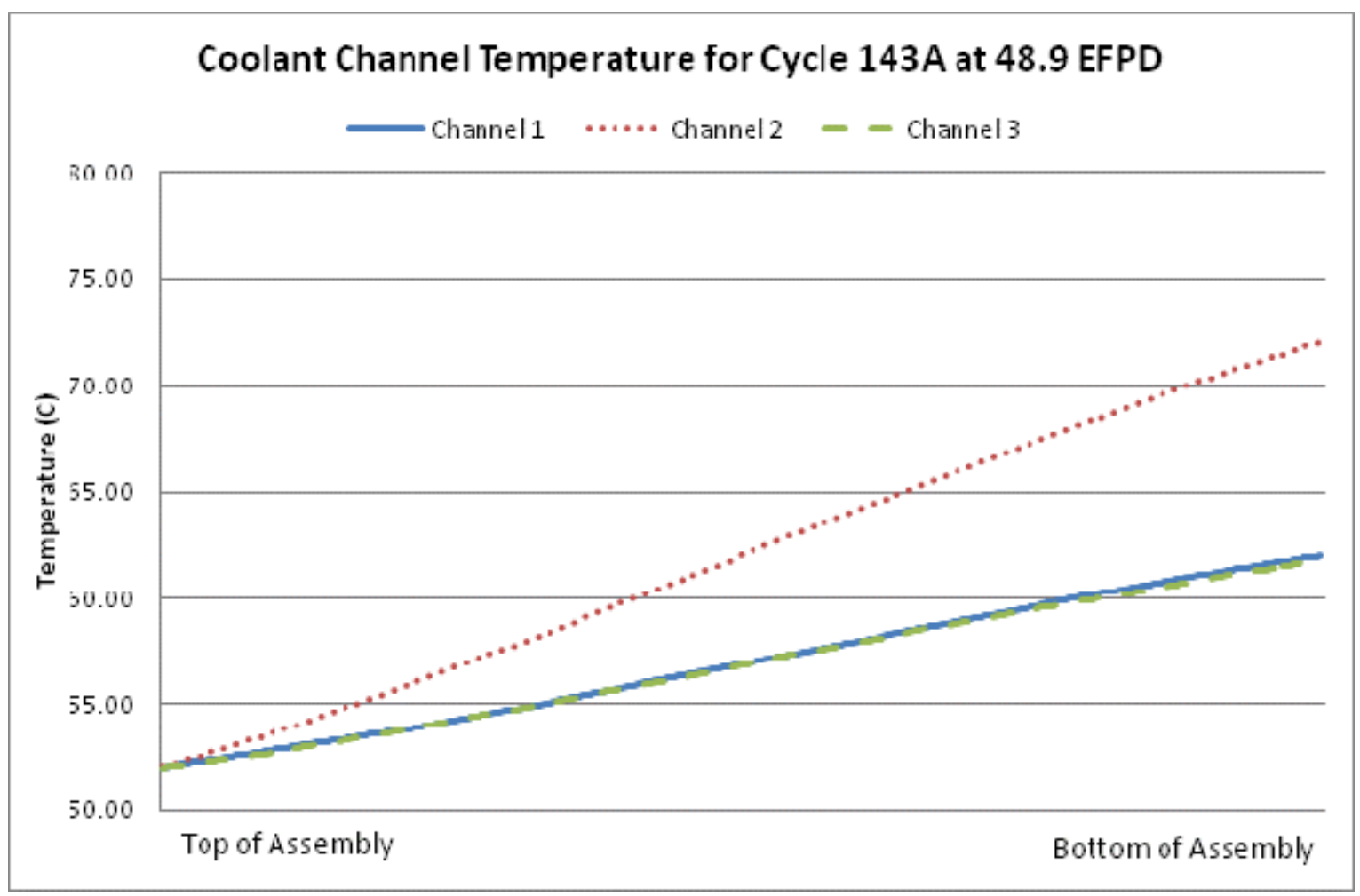

Figure 10. GTL-1 coolant channel temperature along the test assembly for Cycle 143A at 48.9 EFPD. 


\subsection{Plate Surface Temperatures}

The average, maximum and minimum plate temperatures for each time step in Cycle 143A are provided in Table 14 through Table 16.

Table 14. GTL-1 average, maximum and minimum plate surface temperatures for Cycle $143 \mathrm{~A}$ at 18 EFPD.

\begin{tabular}{|c|c|c|c|c|}
\hline $\begin{array}{c}\text { Plate } \\
\text { Location }\end{array}$ & Plate ID & $\begin{array}{c}\text { Average } \\
\text { Temperature } \\
(\mathrm{C})\end{array}$ & $\begin{array}{c}\text { Maximum } \\
\text { Temperature } \\
(\mathrm{C})\end{array}$ & $\begin{array}{c}\text { Minimum } \\
\text { Temperature } \\
(\mathrm{C})\end{array}$ \\
\hline A1 & US06C & 100.06 & 105.85 & 92.52 \\
\hline A2 & US15DM & 99.81 & 118.65 & 89.27 \\
\hline A3 & US03HS & 108.05 & 128.69 & 97.65 \\
\hline A4 & US11GS & 111.16 & 124.74 & 102.61 \\
\hline B1 & US04GS & 117.27 & 142.47 & 104.56 \\
\hline B2 & UN01FS & 117.82 & 134.71 & 107.55 \\
\hline B3 & US02FS & 123.08 & 141.71 & 113.05 \\
\hline B4 & UA01FS & 122.30 & 138.85 & 109.90 \\
\hline C1 & US07FS & 125.69 & 147.28 & 110.15 \\
\hline C2 & US16DM & 124.39 & 147.73 & 109.32 \\
\hline C3 & US08CS & 124.54 & 139.58 & 114.20 \\
\hline C4 & US14DS & 125.44 & 138.26 & 116.18 \\
\hline D1 & US09GS & 123.95 & 144.06 & 106.68 \\
\hline D2 & UN03ES & 120.10 & 138.13 & 105.08 \\
\hline D3 & US13GS & 116.95 & 130.00 & 107.14 \\
\hline D4 & US17GM & 117.19 & 130.09 & 96.14 \\
\hline
\end{tabular}

Table 15. GTL-1 average, maximum and minimum plate surface temperatures for Cycle 143A at 36 EFPD.

\begin{tabular}{|c|c|c|c|c|}
\hline $\begin{array}{c}\text { Plate } \\
\text { Location }\end{array}$ & Plate ID & $\begin{array}{c}\text { Average } \\
\text { Temperature } \\
\text { (C) }\end{array}$ & $\begin{array}{c}\text { Maximum } \\
\text { Temperature } \\
(\mathrm{C})\end{array}$ & $\begin{array}{c}\text { Minimum } \\
\text { Temperature } \\
(\mathrm{C})\end{array}$ \\
\hline A1 & US06C & 97.19 & 102.66 & 90.08 \\
\hline A2 & US15DM & 96.70 & 115.12 & 86.37 \\
\hline A3 & US03HS & 103.73 & 114.18 & 93.68 \\
\hline A4 & US11GS & 105.98 & 118.46 & 98.11 \\
\hline B1 & US04GS & 111.19 & 132.16 & 94.40 \\
\hline B2 & UN01FS & 110.08 & 125.16 & 100.89 \\
\hline B3 & US02FS & 114.63 & 130.58 & 105.93 \\
\hline B4 & UA01FS & 113.83 & 128.84 & 102.99 \\
\hline C1 & US07FS & 116.42 & 135.59 & 102.72 \\
\hline C2 & US16DM & 115.16 & 135.77 & 101.85 \\
\hline C3 & US08CS & 116.00 & 129.40 & 106.74 \\
\hline C4 & US14DS & 116.77 & 128.18 & 108.50 \\
\hline D1 & US09GS & 117.00 & 135.12 & 101.35 \\
\hline D2 & UN03ES & 113.58 & 129.81 & 99.96 \\
\hline D3 & US13GS & 111.98 & 123.80 & 103.08 \\
\hline D4 & US17GM & 112.40 & 124.12 & 92.85 \\
\hline
\end{tabular}


Table 16. GTL-1 average, maximum and minimum plate surface temperatures for Cycle 143A at 48.9 EFPD.

\begin{tabular}{|c|c|c|c|c|}
\hline $\begin{array}{c}\text { Plate } \\
\text { Location }\end{array}$ & Plate ID & $\begin{array}{c}\text { Average } \\
\text { Temperature } \\
\text { (C) }\end{array}$ & $\begin{array}{c}\text { Maximum } \\
\text { Temperature } \\
\text { (C) }\end{array}$ & $\begin{array}{c}\text { Minimum } \\
\text { Temperature } \\
\text { (C) }\end{array}$ \\
\hline A1 & US06C & 93.97 & 99.08 & 87.34 \\
\hline A2 & US15DM & 93.31 & 110.58 & 83.63 \\
\hline A3 & US03HS & 99.35 & 115.92 & 89.81 \\
\hline A4 & US11GS & 101.11 & 112.54 & 93.91 \\
\hline B1 & US04GS & 104.98 & 123.87 & 93.47 \\
\hline B2 & UN01FS & 103.89 & 117.49 & 95.62 \\
\hline B3 & US02FS & 107.94 & 121.91 & 100.15 \\
\hline B4 & UA01FS & 107.16 & 120.81 & 97.51 \\
\hline C1 & US07FS & 109.19 & 126.28 & 96.87 \\
\hline C2 & US16DM & 108.08 & 126.54 & 96.16 \\
\hline C3 & US08CS & 109.01 & 121.05 & 100.68 \\
\hline C4 & US14DS & 109.73 & 119.98 & 102.30 \\
\hline D1 & US09GS & 110.70 & 127.16 & 96.48 \\
\hline D2 & UN03ES & 107.49 & 122.21 & 95.16 \\
\hline D3 & US13GS & 106.78 & 117.58 & 98.70 \\
\hline D4 & US17GM & 107.13 & 117.83 & 89.22 \\
\hline
\end{tabular}




\section{REFERENCES}

1. Hayes, S. L., 2008, "U3Si2/A1 Miniplate Irradiation Test Plan to Support the BFFL Booster Fuel Concept," PLN-2735, February 2008.

2. BFFL Project Personnel, 2008, "BFFL GTL-1 Irradiation Experiment in the Advanced Test Reactor: As-Built Data Package," GTL-1 AS Built, April 2008.

3. Chang, G. S, J. K. Jewell, 2008, "Neutronic Analysis for Final Design of the GTL-1 Experiment Irradiated in ATR South Flux Trap," ECAR-136, August 2008.

4. Moore, G. A., "Fuel Loading Calculations for the GTL-1 Irradiation Experiment," ECAR-164, March 2008.

5. Perez, D. M, G. S. Chang, 2010, "As-Run Neutronics Analysis of the GTL-1 Experiment Irradiated in ATR South Flux Trap,” ECAR-1245 Revision 1, July 2011.

6. Wachs, D. M., 2006, “GTL Mini-Plate Experiment Flow Test,” EDF-7531, November 2006.

7. Bell, K. J., Albright's Chemical Engineering Handbook, Edited by Lyle F. Albright, CRC Press 2008 p.508. 
Appendix A

\section{Individual Plate Power and Burnup}




\section{Appendix A \\ Individual Plate Power and Burnup \\ GTL-1 Capsule A}
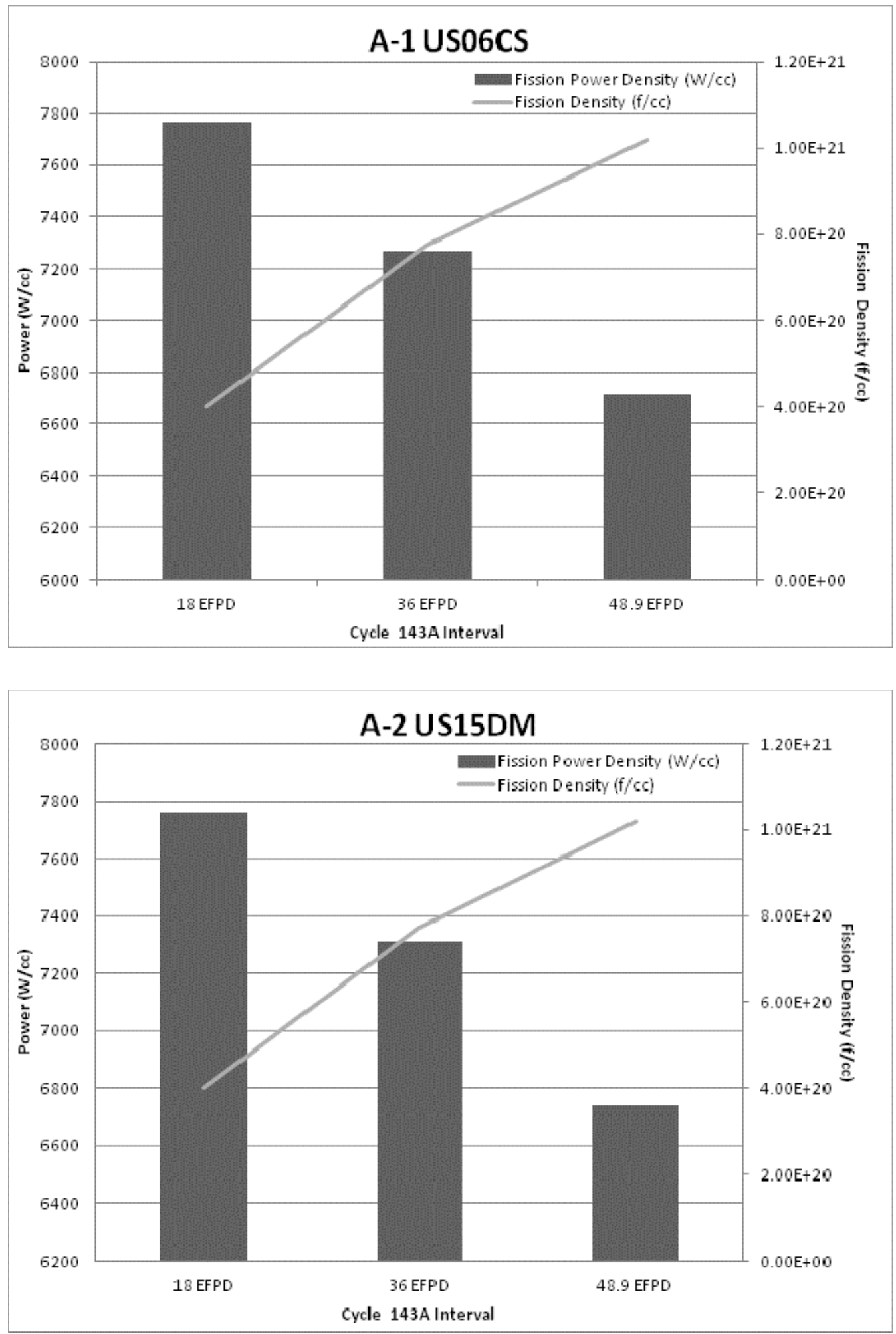

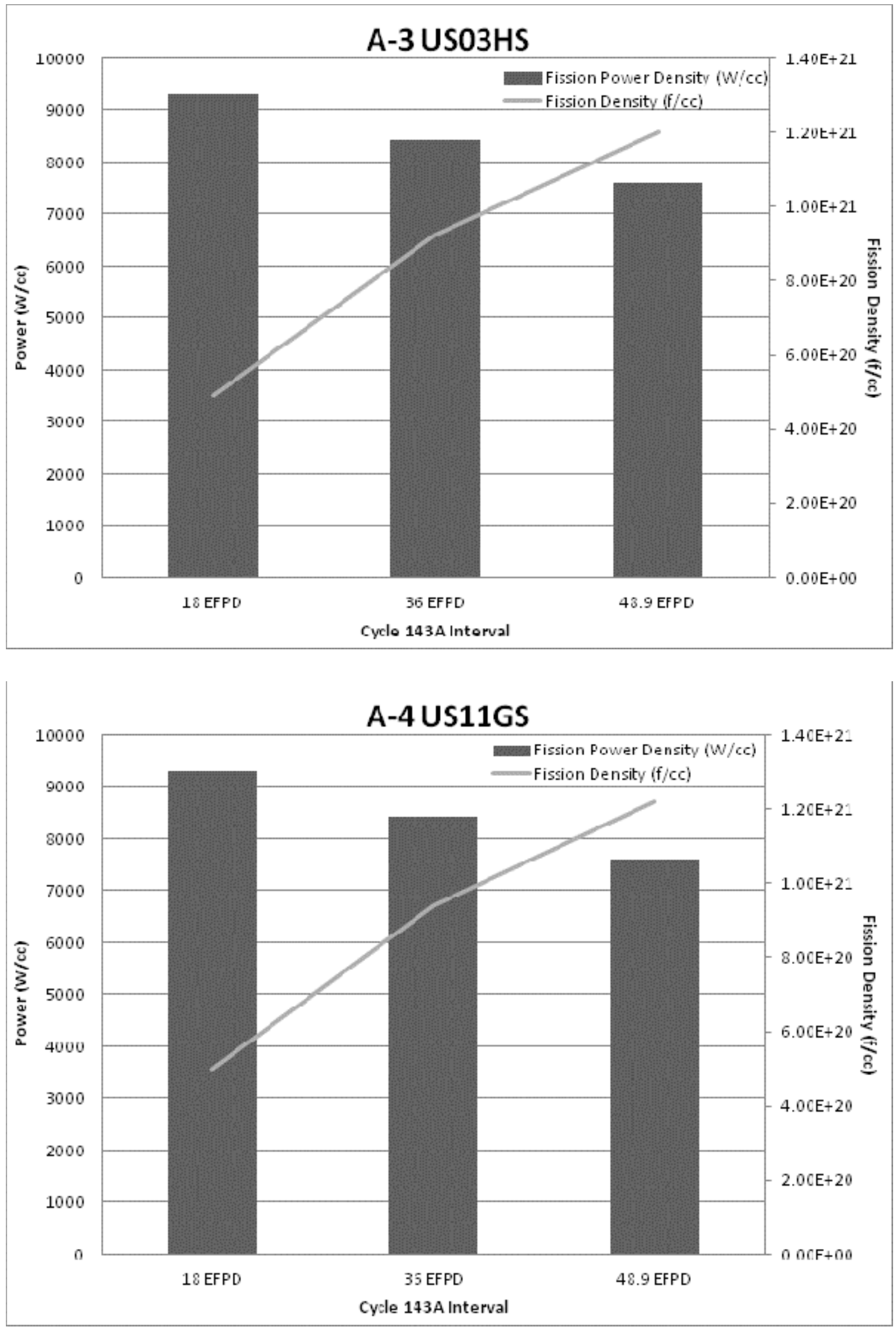


\section{GTL-1 Capsule B}
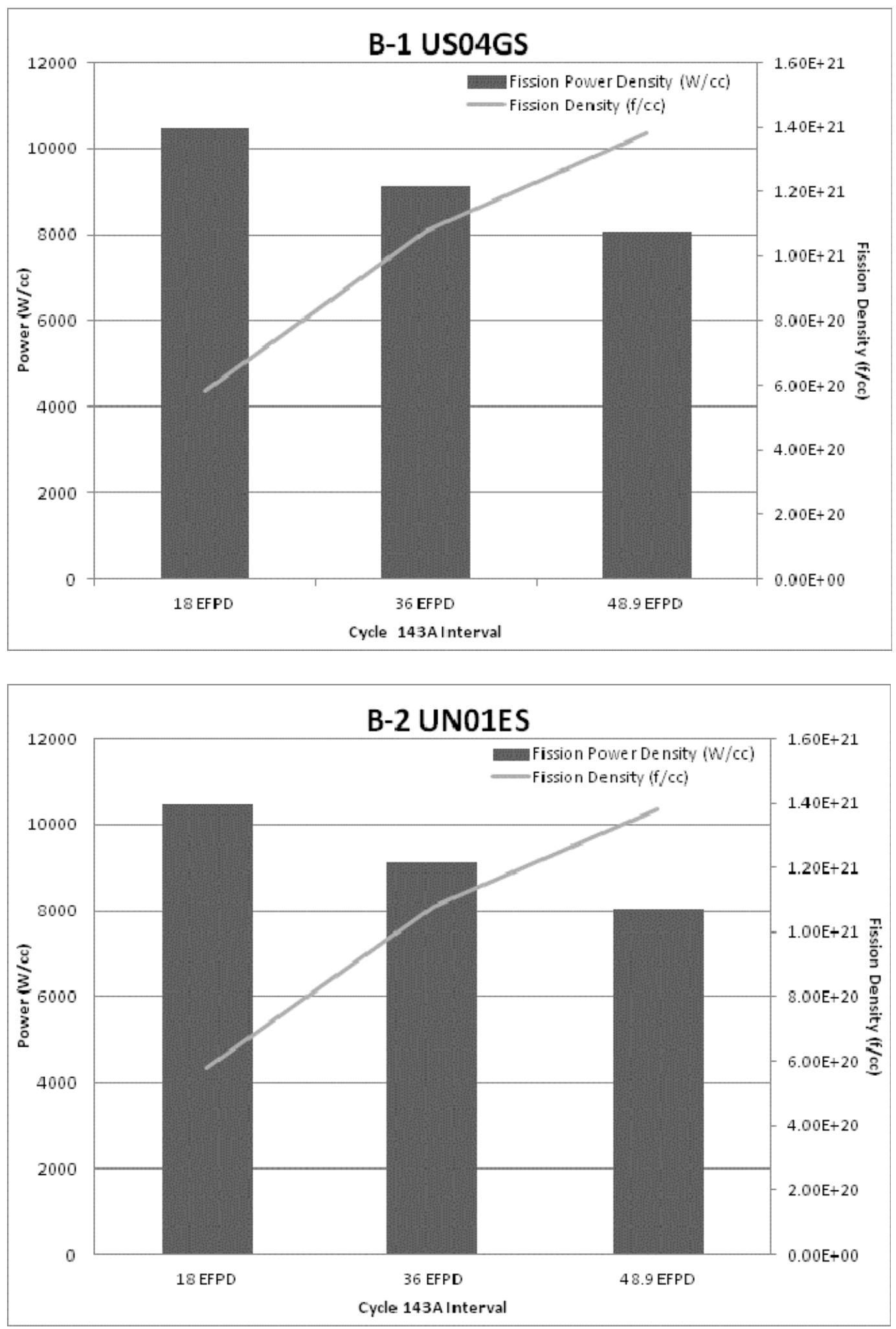

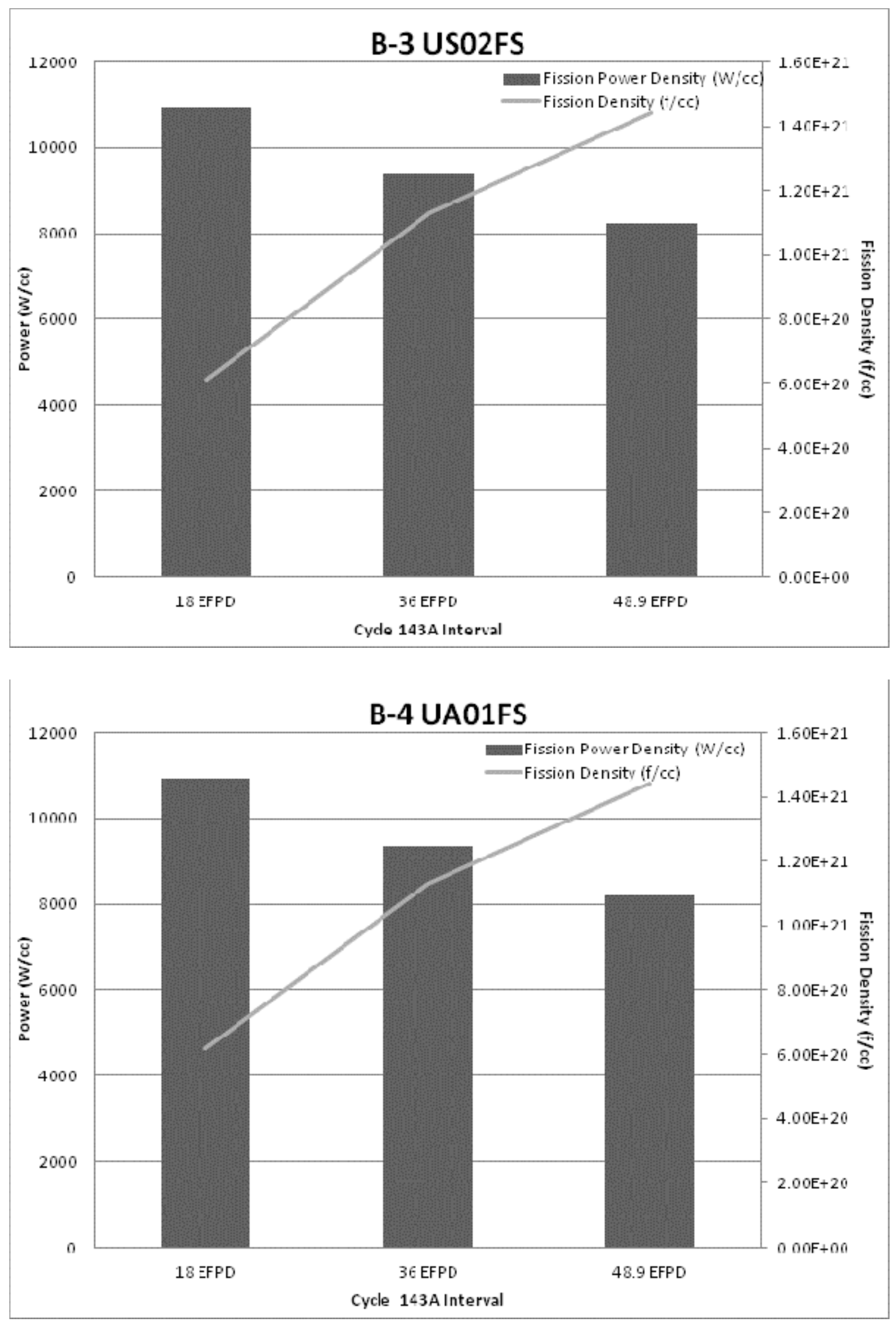


\section{GTL-1 Capsule C}
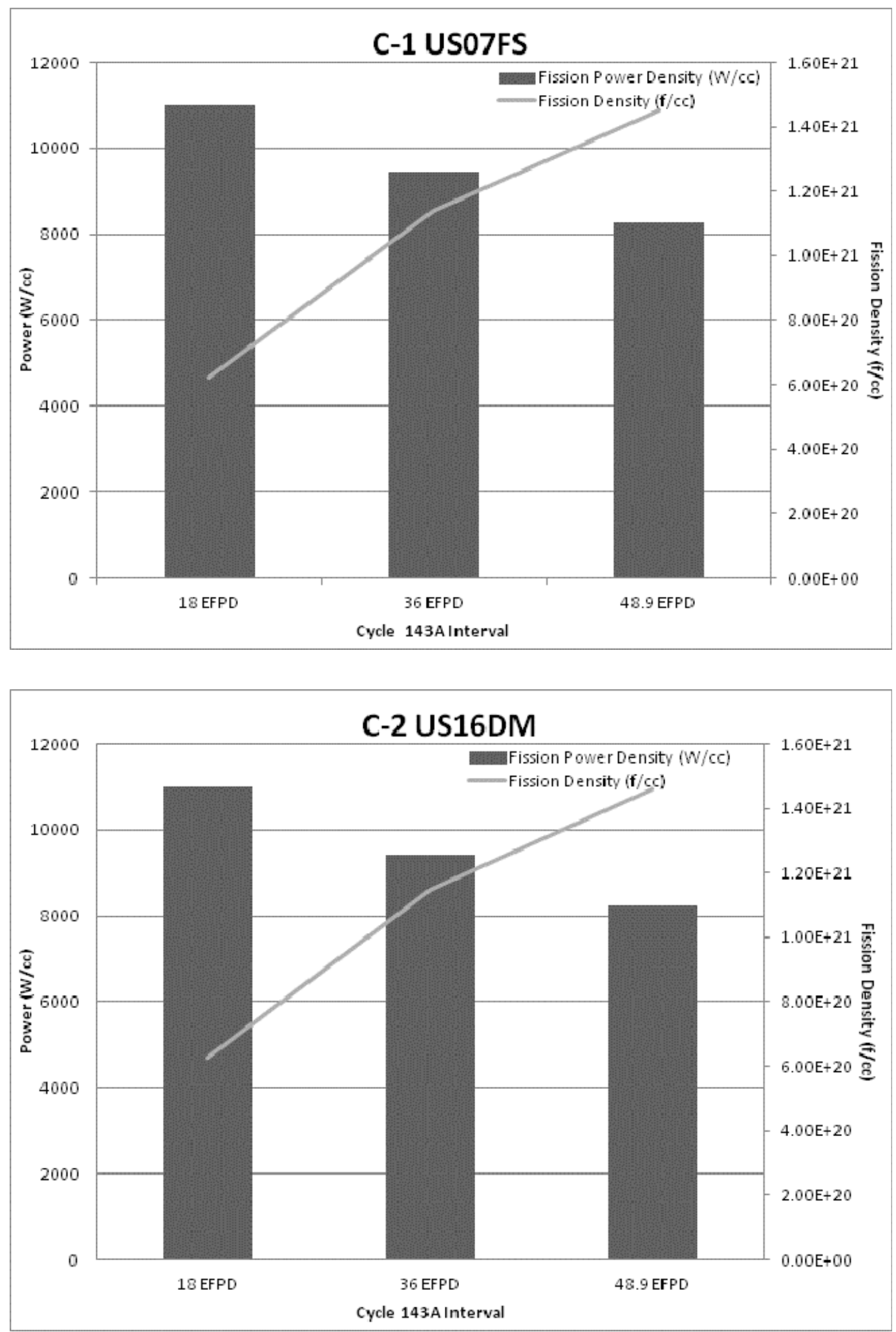

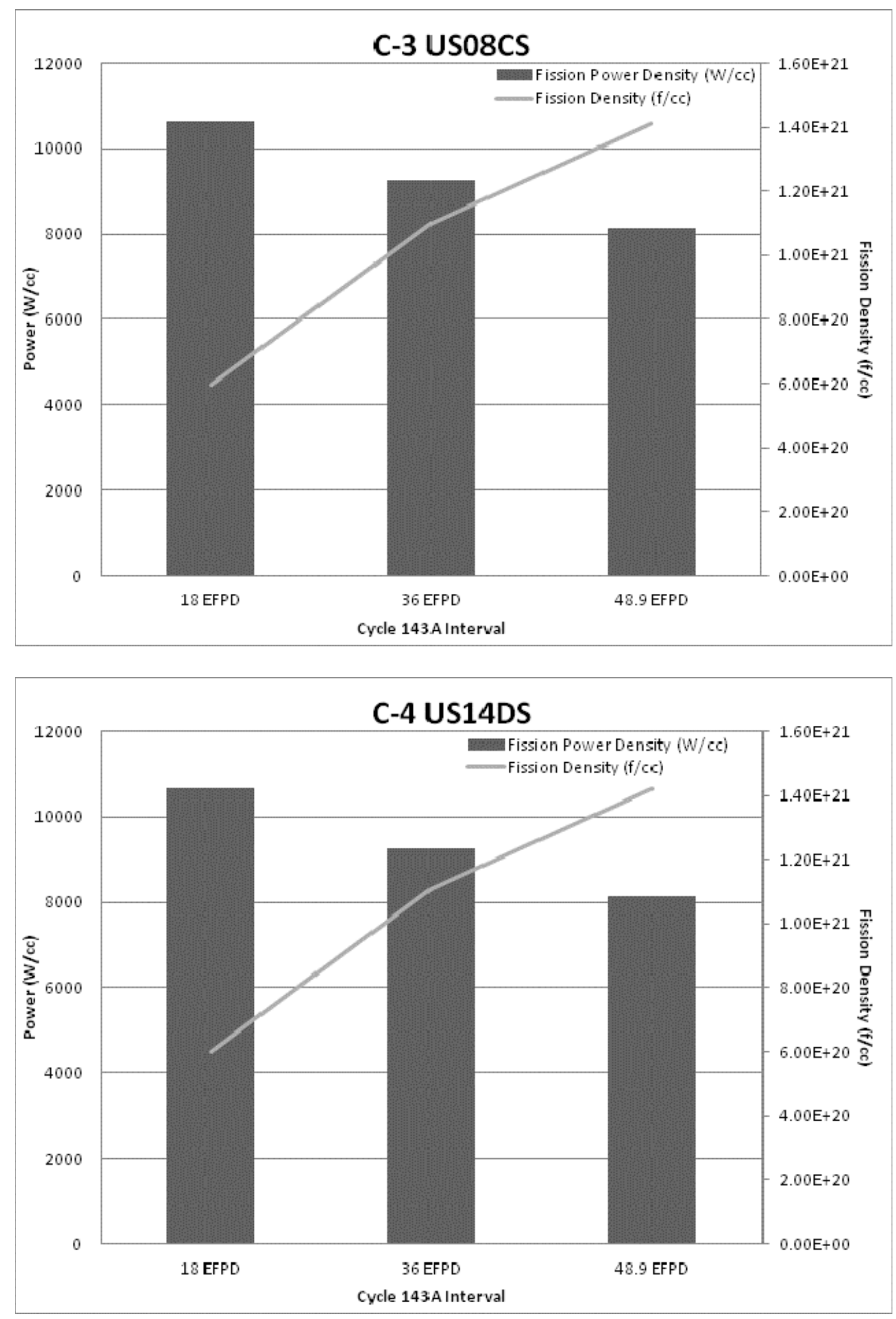
GTL-1 Capsule D
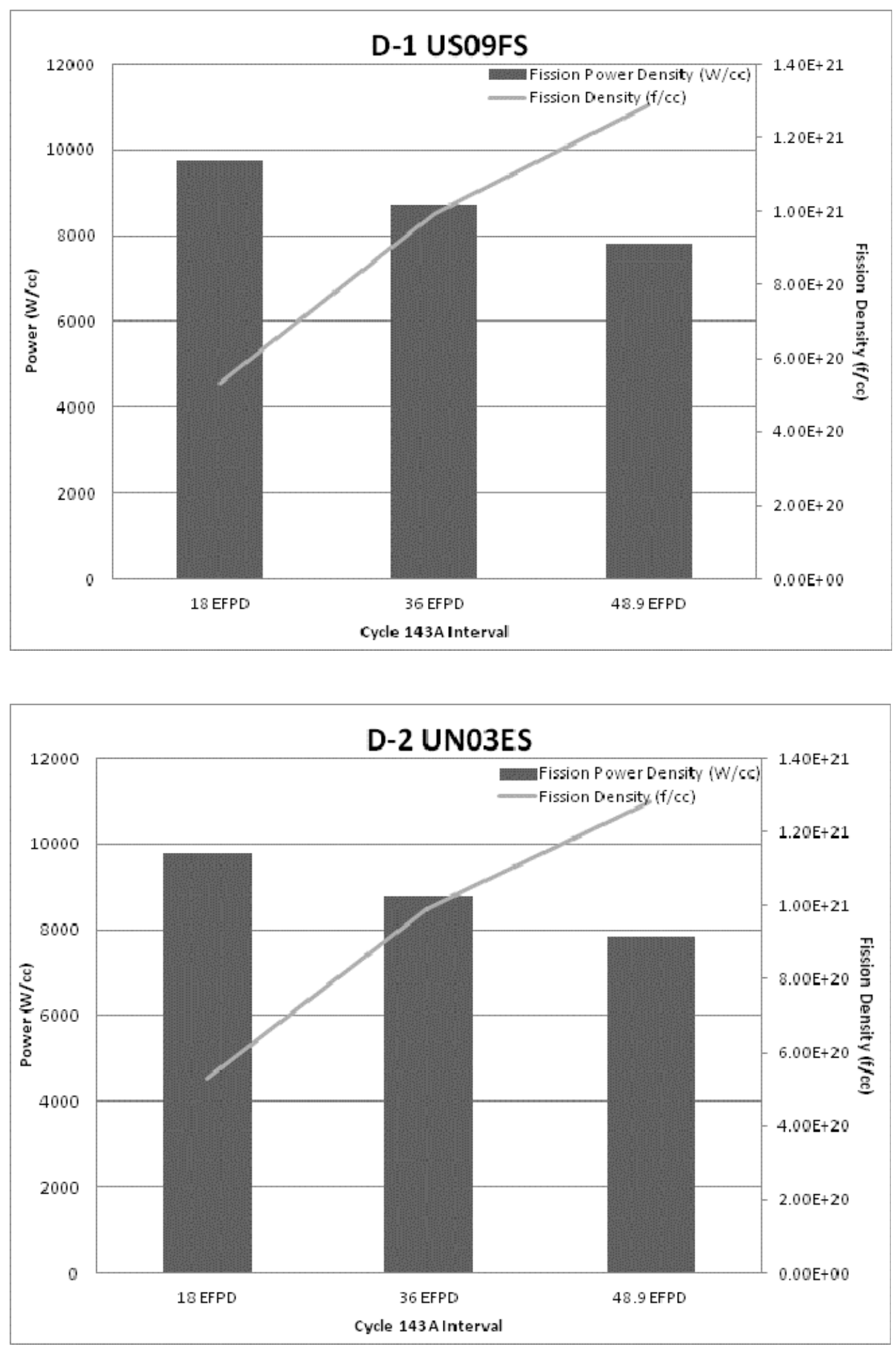

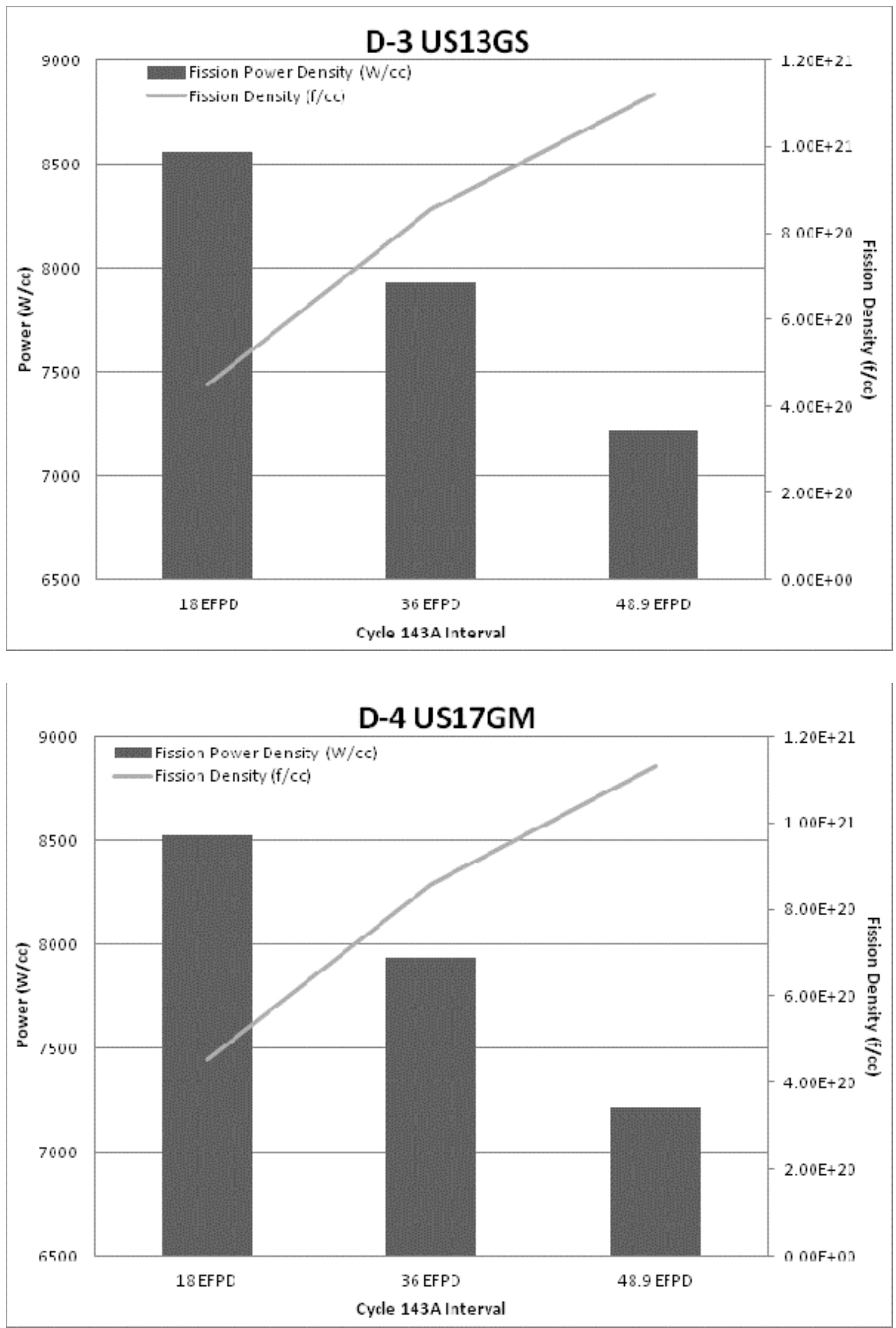